\title{
VASCULAR PLANT BIODIVERSITY RICHNESS AND ENDEMO- RELICTNESS OF THE KARST MOUNTAINS PRENJ, ČVRSNICA AND ČABULJA IN BOSNIA AND HERZEGOVINA (W. BALKAN)
}

\author{
BIODIVERZITETA IN ENDEMO-RELIKTNOST VASKULARNIH \\ RASTLIN KRAŠKIH GOROVIJ PRENJ, ČVRSNICA IN ČABULJA, \\ BOSNA IN HERCEGOVINA
}

\author{
Sulejman REDŽIĆ ${ }^{1,2}$, Senka BARUDANOVIĆ ${ }^{2}$, Sabina TRAKIĆ ${ }^{2} \&$ Dejan KULIJER ${ }^{2}$
}

\begin{abstract}
UDC 581.52:574.1(497.6)

Sulejman Redžić, Senka Barudanović, Sabina Trakić \& Dejan Kulijer: Vascular plant biodiversity richness and endemorelictness of the karst mountains Prenj-Čvrsnica-Čabulja in Bosnia and Herzegovina (W. Balkan)

The complex of karstic mountains Prenj-Čvrsnica and Čabulja in Herzegovina (W. Balkan) is characterized by high level of both geomorphology and biodiversity richness. This has been confirmed by a research of plant communities, their structure and dynamics, which took place throughout several seasons from 2005 to 2008. In the investigated area the vegetation cover, as a reliable indicator for specific karstic circumstances, is being differentiated in a great number of syntaxa (plant communities) that encompass over 2,500 vascular plants. On the surface of about 100,000 ha identified were up to 236 plant associations, 116 alliances and 63 vegetation orders that belong to 34 classes. This amounts $34 \%$ of total of vegetation classes at the European level and $100 \%$ of so far known vegetation classes in Bosnia and Herzegovina, over $80 \%$ of classes at the level of Montenegro and Croatia. There have been identified nearly 450 endemic and relict species, which is why most of the identified communities are endemic and relict ones, not only at the level of association but also at the level of higher syntaxonomic categories, such as alliance and order. The highest diversity level characterizes those communities that make a direct contact with the calcareous geological foundation either in rock crevices belonging to the class Asplenietea trichomanis Br.-Bl. 1934 corr. Oberd. 1977, or screes on limestone that are comprised by the classes Thlaspietea rotundifolii Br.-Bl.1948 and Drypetea spinosae Quezel 1967, then sub-alpine and alpine pastures Elyno-Seslerietea Br.-Bl. 1948, and rocky grasslands Thero-Brachypodietea Br.-Bl. 1947. That high level of floristic and vegetation richness places this area among the most diverse areas both in Europe and whole Mediterranean. Such pattern of vegetation
\end{abstract}

Izvleček UDK 581.52:574.1(497.6)

Sulejman Redžić, Senka Barudanović, Sabina Trakić \& Dejan Kulijer: Biodiverziteta in endemo-reliktnost vaskularnih rastlin kraških gorovij Prenj, Čvrsnica in Čabulja, Bosna in Hercegovina

Območje gorovij Prenj, Čvrsnica in Čabulja odlikuje velika geomorfološka pestrost in biodiverziteta. To potrjuje tudi raziskava strukture in dinamike rastlinskih združb, ki je potekala med leti 2005 in 2008 . Vegetacijski pokrov je pomemben indikator okolja. $\mathrm{V}$ območju raziskav smo določili veliko število rastlinskih združb, ki zajemajo več kot 2500 vaskularnih rastlin. Na površini 100.000 hektarov smo določili 236 asociacij, 116 rastlinskih zvez in 63 vegetacijskih redov, ki pripadajo 34 razredom. Zastopanih je kar $34 \%$ razredov, ki jih poznamo v Evropi, vsi razredi Bosne in Hercegovine ter 80 \% razredov, poznanih na Hrvaškem in v Črni gori. Prepoznanih je bilo 450 endemičnih in reliktnih vrst, kar pomeni, da je večina združb endemičnih oziroma reliktnih tako na ravni asociacij, kot tudi na ravneh zvez in redov. Največja diverziteta je značilna ob neposrednem stika $\mathrm{z}$ apnenčasto podlago. Tako $\mathrm{v}$ razpokah najdemo pripadnike razreda Asplenietea trichomanis (Br.-Bl. 1934 corr. Oberd. 1977), za melišča so značilni razredi Thlaspietea rotundifolii Br.-Bl.1948 in Drypetea spinosae Quezel 1967, alpske pašnike Elyno-Seslerietea Br.-Bl. 1948 in za kamnite travnike Thero-Brachypodietea Br.-Bl. 1947. Veliko floristično in vegetacijsko bogastvo uvršča območje med tista $\mathrm{z}$ največjo diverziteto $\mathrm{v}$ Sredozemlju in Evropi, kar potrjuje izjemen ekološki pomen Dinarsko-hercegovskega krasa.

Ključne besede: Dinarski kras, vegetacija, sintaksonomija, kraški biotope, kanjon Neretve, endemične in reliktne rastlinske vrste, zatočišče, interpretacija z GIS.

\footnotetext{
${ }^{1}$ Academy of Sciences \& Art of Bosnia and Herzegovina, Sarajevo, Bosnia and Herzegovina, tel./fax: +387 33649196 , e-mail: sredzic@anubih.ba

${ }^{2}$ Center of Ecology \& Natural Resources of the Faculty of Science of University of Sarajevo, Bosnia and Herzegovina
}

Received/Prejeto: 7.9.2010 
(syntaxonomy) and floristic diversity confirms undoubtedly the unique role of dinaric-herzegovina's karst as a complex of unrepeatable ecological factors on global scale.

Keywords: Dinaric karst, vegetation, syntaxonomy, karst biotopes, Neretva canyon, endemic and relict plants, refuge, GIS interpretation.

\section{INTRODUCTION}

In the entire world, there have been noted specific patterns of diversity in terms of geomorphology, hydrology and biology which are closely related with karst (Katzer 1909; Riter-Studnička 1959; Fairbridge 1968; Herak \& Stringfield 1972; Bonaci 1987; White 1988; Božičević 1992; Redžić 1997; Kogovšek et al. 1999; Kranjc 2002; Verovnik et al. 2004; Klimchouk et al. 2006; Franciskovic-Bilinski et al. 2004; Florea \& Vacher 2007). However, there are some specific features regarding its geogenesis, hydro genesis and syngenesis that characterize the karst of Dinaric Alps (Cvijić 1893; Bognar 1987; Kranjc 1994; Culver \& Sket 2002; Brancelj 2006; Redžić 2008a). All that had led to the creation of diverse karstic phenomena, such as: karren, sinkholes, poljes, caves, which made the dinaric karst recognizable around the world (Katzer 1909; Milanović 1979; Spahić 2001; Sket et al. 2001; Trinajstić 2008). Apart from karst poljes, on the territory of mid Dinaric Alps (W. Balkan) entire mountain complexes with numerous karstic attributes occur. Among them special place is taken by the mountains that stretch along the Adriatic coastline from NW to SE (Sliskovic 1995; Prohić et al. 1997; Lučić 2003; Redžić 2007a). The most unique patterns of karstic-genesis have caused the creation of not only rich over ground and underground orography, but also extremely high biodiversity richness at all levels (Kušan 1969; Horvatić 1963; Lakušić 1970; Horvat et al. 1974; Lakušić \& Redžić 1989, 1991; Topić \& Ilijanić 2005, Redžić 2007b;).

One of the mountain complexes which contain rarely repeatable forms of karstic diversity is the complex of mountains around the Neretva river: Prenj and Velež in east and southeast, Čvrsnica, Vran and Čabulja in west and southwest, on the territory of Herzegovina (Katzer 1926; Šilić 1967, 1979, 1984; Lepirica 2008). In spite of that, this area is still relatively poorly investigated; especially its biodiversity for it is the best indicator of karstic diversity and karst as the most unique complex of ecological factors. The investigation of plant cover (Murbeck 1891; Beck-Mannagetta 1901; Adamović 1907; Horvat 1933, 1941; Riter-Studnička 1954; Ilijanić \& Hršak 1990) so far has shown high level of endemism and relictness of vascular flora, as well as of fauna of some animal groups
(Sket 1997; Sijarić 2000). Apart from the floristic richness, the investigation of syntaxonomic diversity so far has confirmed the existence of several both endemic and steno endemic plant communities, of which some are exclusively associated with this area, such as Minuartio handelii-Caricetum Bjelčić \& Šilić 1979 at the top of Veliki Vilinac, Heliospermo retzdorffiani-Oreoherzogietum illyricae Šilić 1970. In the canyon of Neretva river, of about 2,000 m height, and canyons of its tributaries: Rakitnica, Ljuta, Trešanica Idbar, Bijela, Neretvica, Doljanka, Glogošnica and Drežanka, special refugia of both flora and vegetation from Tertiary, which are characterized by extreme richness (Šilić 2000; Redžić 2004, 2008b), are identified. There are many leads that this area represents special a kind of the biodiversity hotspot, which should be more closely clarified through further investigation. The investigation that has been conducted so far indicates the existence of development endemic-relict centre situated both at the mountain foots and their peaks as well. Here have evolved many tertiary and glacial relicts.

As a special indicator for this richness is considered to be the syntaxonomic diversity which integrates the diversity of both flora and habitats (Ilijanić 1989; Barudanović \& Redžić 2006; Redžić 2007c, 2008c, 2008d; Čarni et al. 2009). Besides, the syntaxonomic diversity is the excellent indicator for the entire ecological diversity. In addition to its fundamental significance, the syntaxonomic diversity can be applied like a tool for the sustainable management in this, every day more threatened, karstic area. This implies that the syntaxonomic diversity can be a basis for successful biological and ecological in situ conservation. Through this investigation formulated was the hypothesis that extremely high level of floristic diversity correlates closely with the syntaxonomic (vegetation) diversity. Main target of this paper was to assess the syntaxonomic diversity in relation to process of karst-genesis, especially in such habitats where the influence of karstic foundation is the most direct in terms of speciation, ended-genesis, such is the case with rock crevices and screes. This kind of approach will undoubtedly illustrate the crucial role of this dinaric karst area in terms of biodiversity patterns. 


\section{PHYSIO - GEOGRAPHIC FEATURES OF ENDEMIC DEVELOPMENT CENTER OF PRENJ, ČVRSNICA AND ČABULJA MOUNTAINS}

\section{GEOGRAPHIC POSITION}

The investigated area is situated in the complex of high mountains of Herzegovina and determined by coordinates $17^{\circ}$ and $19^{\circ} \mathrm{E} ; 43^{\circ}$ and $44^{\circ} \mathrm{N}$. The considered area represents high upland framework constituted of Prenj, Čvrsnica and Čabulja mountains. It is positioned in northern Herzegovina, in the area of middle and upper flow of Neretva river (Fig. 1).

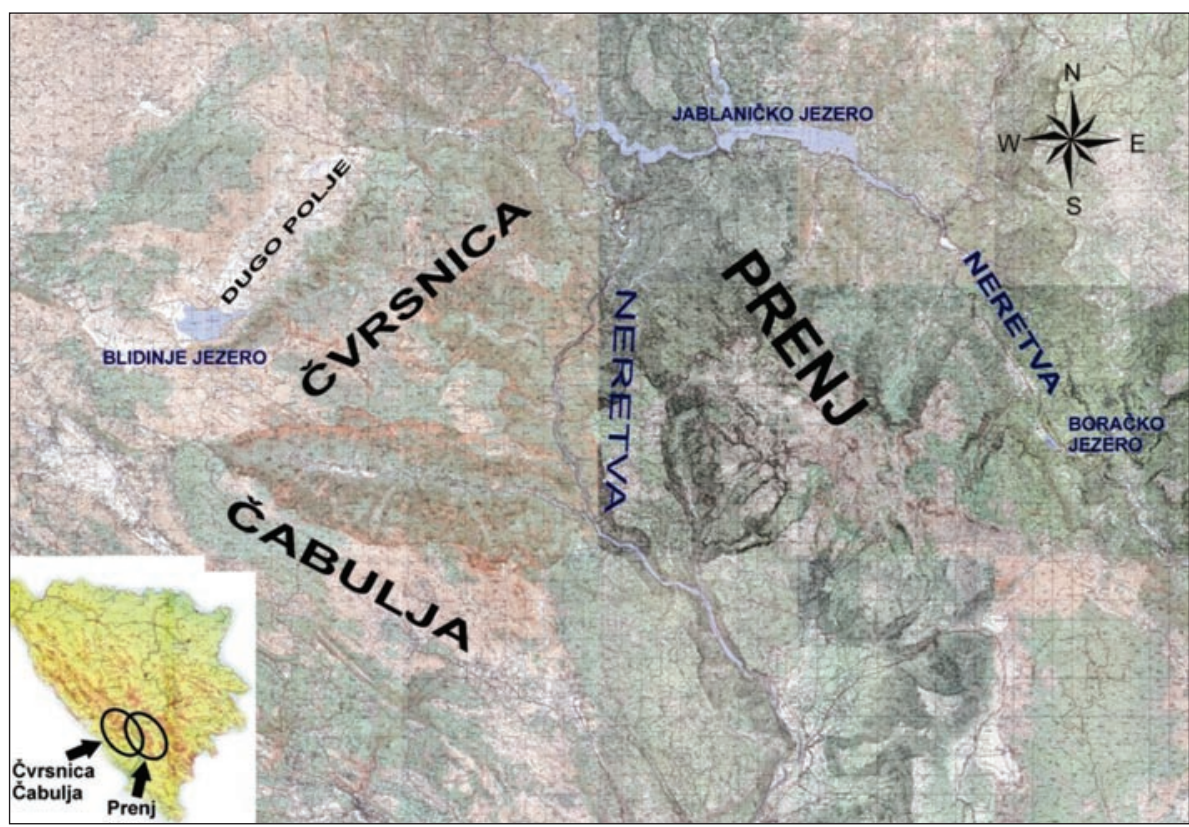

Fig. 1: Geographic position of endemic development centre of Prenj, Čvrsnica and Čabulja mountains on the territory of W. Balkan.

As far as geographic regionalization is concerned, this territory is part of Bosnia and Herzegovina that belongs to high karst macro-region or its subunit, meso region of northern Herzegovina's upland. The territory takes approximately $1,000 \mathrm{~km}^{2}$, stretching from the accumulation lake of Jablanica in the North to Bjelopoljska valley in the South, and from the surrounding of Boračko lake in the East to distant north-western slopes of Čabulja mountain in the West.

In the physical and geographical sense, the concerned part of Neretva river basin is distinguished by its relief, climate, soils, as well as by its geological, hydrological and biological diversity. Afore named attributes and specific geographical position have affected this relatively small area in a way that it became rich in natural values and distinguished by extremely high level of geoand biodiversity (Miladinović 1964).

\section{GEOLOGY}

The investigated area, after geological classification on regional scale, is a part of the Outer or karstic Dinaric Alps, which is the subunit of Dinaric Alps (Cvijić 1989). "Dinaric Alps involve structural complex of carbonate platform with relatively unified carbonate sedimentation (calcite and dolomites) with several intrusions of bauxite, breccias etc. The structural relationships inside the Dinaric Alps are rather complex. Differences in altitude are induced by elevation, differences in erosion rate, filling of local and regional valleys with new depositions, but also by previous secondary (tectonic) accumulation of structural complexes in form of scaling and drawing." (Herak 1983).

Movements in vertical sense, which took place at the end of Neogen and during Quaternary, have resulted in rising of faulting of Prenj, Čvrsnica and Čabulja massifs to their current height and creation of Neretva river canyon with deeply truncated valleys of its tributaries. The most frequently occurring is Mesozoic alluvium - of Triassic, Jurassic or Cretaceous age (Katzer 1926; Čičić \& Pamić 1979; Čičić et al. 1984; Lepirica 2005).

The most dominant lithological units are limestone, dolomites and limestone and dolomites combined. The geologically most recent alluvial deposition covers the valley bottom just beneath the mountain slopes. Mountain lakes are often associated with glacial processes, which has led to development of special kind of plant communities.

\section{OROGRAPHY}

In the geomorphologic sense, the investigated area of Neretva river basin is situated in the mega-geomorphologic region of Dinaric Alps of Bosnia and Herzegovina. More precisely, the area of Prenj, Čvrsnica and Čabulja mountains, as well as of valleys of Neretva river and its tributaries, belong to the geomorphologic meso-region of the middle Dinaric Alps. By its morphology, this en- 
tire area has got polygenetic features due to influences of several geomorphologic factors which took effects at the moment of its creation and development. It is important to stress that the relief development in northern Herzegovina was primarily affected by active exogene geomorphic processes.

The morphological structures of Prenj mountain $(2,155 \mathrm{~m})$, Čvrsnica mountain $(2,228 \mathrm{~m})$ and Čabulja mountain $(1,798 \mathrm{~m})$, as they are today, were predisposed by massive neo-tectonic uplift during Quaternary (Bušatlija 1974; Lepirica 2005, 2008).

In the past, specific forms of both geo- and geomorphogenesis that were followed by karstogenesis have resulted in extremely high relief diversity and uniqueness of geomorphological shapes going from the lowest to the highest positions of this karstic complex. The diversity in terms of geomorphology represents one of the crucial determinants of most unique biodiversity in which many endemo-relict both species and communities are contained.

\section{HYDROLOGY}

Main hydrological features to the entire complex of Prenj, Čvrsnica and Čabulja mountains are undoubtedly given by Neretva river and its tributaries. From the Neretva's spring toward Mostar city, its right affluents are as follows: Ljuta, Trešanica, Neretvica, Doljanka, Grabovica and Drežnica. The most important affluents along the left river bank are: Lađanica, Konjička Bijela, Idbar, Glogošnica, Mostarska bijela. Today, the most impressive part of the Neretva's canyon, its mid part, between Prenj, Čvrsnica and Čabulja mountains, is turned into artificial hydro-accumulation lakes "Grabovica" and "Salakovac".

The upper flow of Neretva river, from its spring under Gredelj and across Bjelopoljska valley, drains vast area of northern and northeastern Herzegovina.

Based on the identified boundary, the surface basin of upper and middle flow of Neretva river covers the area of about 2,500 $\mathrm{km}^{2}$. However, due to profoundly karstified structure of this surrounding, which is built of tick carbonate and dolomite layers from Mesozoic, the surface is holed and cut by a system of crevices, gaps and chennels, making the hydrological network become disarranged and transmitted into karstic underground. Hence, the extent of catchment area cannot be defined precisely. As an example, in the Kalinovačko Zagorje a sinking creek that flows on the right side from the village Jelašce, corresponds with Gornji and Donji Vrutak, which are actually springs that belong to the catchments area of Bistrica creek. Furthermore, the adjacent Tatinac creek and sinking creek at Kalinovik carry large quantity of water into the Neretva river. The latter represents aquatic linkage with the biggest spring in upper Neretva area - Krupac. These underground currents appear on the surface as powerful karstic springs, differing in their abundance, functionality and stability. Mostly, they don't flow on the surface for a long time.

The fluctuation of water level in Neretva river is uneven over a year. After it reaches maximum in first half of May, water level declines slowly and outflow falls down to reach its lowest values in August and September. From October, with increased precipitation, the outflow rises and reaches its maximum in the middle of November and over entire December. Due to large ice quantities and thick snow cover, including low temperatures in mountainous area, water level stagnates in January and February, which is followed by its slow rising in March. From the year 1926 to 1980 the following absolute values of Neretva's outflow were obtained: absolute maximum in outflow was measured to be $926 \mathrm{~m}^{3} / \mathrm{s}$, while the absolute minimum was $4 \mathrm{~m}^{3} / \mathrm{s}$. The average annual outflow of Neretva river at Konjic was $52.3 \mathrm{~m}^{3} / \mathrm{s}$ (Lepirica 2007).

In the investigated area occur only several permanent natural lakes. These lakes are: Boračko and Blidinjsko lake, and on Čvrsnica mountain: Crvenjak, Gavranić and Lake on Mejdan, including Jezerce and lake under Vršine on Prenj mountain, which are small and of no hydrological importance. Their sole function is to provide cattle with water. Many of these lakes arose by blocking the bottom of sinking rivers that was carried out by cattle breeder, likewise Crepulja on Plaso. The Boračko lake is considered to be the biggest and most important natural hydro-accumulation in the upper flow of Neretva river (Spahić 2001). The hydrological regime in highmountainous area is strongly influenced by ice and snow retained for a long time. Large quantities of snow are being retained at the bottom of sinkholes over entire summer. This kind of habitats became shelters for numerous relict both species and communities during glaciation. Beneath mountain glaciers are to be found many unique springs with cold and fresh water. One of such springs is the spring of Jasle beneath Pločno peak in the natural reserve with well preserved woods of endemic Bosnian pine (Pinus heldreichii H.Christ).

\section{ECO-CLIMATE}

The exceptional vertical differentiation of relief that includes pronounced de-levelling in altitude and protrusion of influences from mild Mediterranean climate (coming through the valley of Neretva river in reduced extent) have had a major impact on development of several climate types and subtypes occurring at this relatively small area.

The area around Neretva river is characterized by modified Mediterranean climate. In the surrounding, at higher altitude, climate changes into sub-montane. Over 
1,000 $\mathrm{m}$ above sea level, montane climate stretches over major part of this watershed. At altitude over 1,700 m, on cliffs and crests of Prenj, Čvrsnica and Čabulja mountains climate is alpine, harsh and cold. At lower altitudes, between 200 and $450 \mathrm{~m}$ above sea level, valleys of Neretva's tributaries are deeply cut in mountains; hence, the area is affected by transitional climate influences with cantonal features (Lepirica 2007).

Based on records of mean air temperatures both monthly and annually, as well as on precipitation rate, measured at the nearest weather stations in this region (Mostar, Jablanica, Konjic and Nevesinje) (Tabs. 1-4) supervenes that different climate types occur: (i) modified-Adriatic climate (at the lowest positions) which protrudes all the way up to Jablanica in North, (ii) Adriatic climate (southern slopes of Prenj mountain toward Mostar city), (iii) transitional lowland climate (mid and upper flow of the Neretva river), (iv) pre-montane and montane climate, taking places above $700 \mathrm{~m}$ above sea level, and (v) alpine climate above $1,700 \mathrm{~m}$.

\section{HUMIDITY OF ECO-CLIMATE}

Climate humidity is an extremely important parameter for determination of not only the type and character of climate, but also for definition of vegetation character in- cluding its tendencies in relation to future syngenesis. The climate humidity is defined by precipitation quantity under given temperature conditions. It is expressed in several ways. In ecology as a very practical and widely accepted interpretation of this parameter has been confirmed to be the method after Gračanin (1950). After this methodology, ratio between precipitation quantity (monthly or annually) and mean temperature of air (monthly or annually) represents rain factor (RF) (Tabs. 1-4). Due to high precipitation rate, the ecoclimate at each meteorological station is highly humid. However, the ecoclimate in vegetation season becomes either semiarid or arid resulting in the development of xero-thermophyllous vegetation encompassed by orders Ostryo-Carpinetalia orientalis Lakušić, Pavlović \& Redžić 1982 and Quercetalia pubescentis Br.-Bl. (1931) 1932, which occur at lower mountain parts (Tabs. 1-4).

\section{WARM CHARACTER OF ECO-CLIMATE}

Regarding its warmth character the ecoclimate is very diverse. It is nivale over winter (the meteorological station Nevesinje) and warm, even hot, in summer (Tabs. 1-4). This warm climate correlates positively with the development of thermophyllous vegetation units from the class Querco-Fagetea Br.-Bl. \& Vlieg. 1937, and thermophyl

Tab. 1: Characteristics of eco-climate noted at meteorological station Nevesinje.

Legend: Humidity (for tab. 1-4): ph - per humid; $h$ - humid; sh - semi humid; sa - semi arid. Warm character of eco-climate** (For tab. 1-4): $n$ - nivale; $h l$ - cold; uhl-temperate cold; $t$-warm; $v$ - hot; ut-temperate warm

\begin{tabular}{|c|c|c|c|c|c|c|c|c|c|c|c|c|c|}
\hline \multicolumn{14}{|c|}{ Meteorological Station: NEVESINJE (900 m) } \\
\hline Month & $I$ & II & III & IV & $V$ & VI & VII & VIII & IX & $x$ & $X I$ & XII & $\begin{array}{l}\text { Average } \\
\text { annual value }\end{array}$ \\
\hline Precipitation (mm) & 161 & 175 & 161 & 118 & 148 & 101 & 74 & 62 & 118 & 160 & 213 & 280 & 1.771 \\
\hline Temperature $\left({ }^{\circ} \mathrm{C}\right)$ & -1.2 & 0,2 & 2.9 & 7.7 & 12.5 & 15.6 & 18 & 18.4 & 14.6 & 10.6 & 5.9 & 1.1 & 8.9 \\
\hline RF m (Gračanin) & 159.8 & 875 & 55.51 & 15.32 & 11.84 & 6.47 & 4.11 & 3.36 & 8.08 & 15.09 & 36.1 & 254.5 & 198.98 \\
\hline Humidity* & ph & ph & ph & ph & $\mathrm{h}$ & sh & sa & sa & $h$ & ph & ph & ph & ph \\
\hline $\begin{array}{l}\text { Warm character of } \\
\text { ecoclimate }\end{array}$ & $\mathrm{n}$ & $\mathrm{n}$ & $\mathrm{n}$ & uhl & $\mathrm{t}$ & $\mathrm{t}$ & $\mathrm{t}$ & $\mathrm{t}$ & $t$ & ut & uhl & hl & ut \\
\hline
\end{tabular}

Tab. 2: Characteristics of eco-climate noted at meteorological station Mostar.

\begin{tabular}{|c|c|c|c|c|c|c|c|c|c|c|c|c|c|}
\hline \multicolumn{14}{|c|}{ Meteorological Station: MOSTAR (65 m) } \\
\hline Month & I & II & III & IV & $V$ & VI & VII & VIII & IX & $x$ & $X I$ & $X I I$ & $\begin{array}{l}\text { Average } \\
\text { annual value }\end{array}$ \\
\hline Precipitation $(\mathrm{mm})$ & 163 & 150 & 134 & 123 & 92 & 84 & 46 & 62 & 99 & 136 & 220 & 230 & 1.539 \\
\hline Temperature $\left({ }^{\circ} \mathrm{C}\right)$ & 4.7 & 6.2 & 9.7 & 13.8 & 18 & 22 & 25 & 24.8 & 20.8 & 15.6 & 10.7 & 6.8 & 14.8 \\
\hline RF m (Gračanin) & 34.68 & 24 & 13.81 & 8.91 & 5.1 & 3.8 & 1.8 & 2.5 & 4.75 & 8.71 & 20.6 & 33.82 & 103.99 \\
\hline Humidity & ph & ph & $\mathrm{h}$ & $\mathrm{h}$ & sh & sa & a & a & sa & $\mathrm{h}$ & ph & ph & ph \\
\hline $\begin{array}{l}\text { Warm character of } \\
\text { ecoclimate }\end{array}$ & uhl & uhl & ut & $\mathrm{t}$ & $\mathrm{t}$ & v & v & v & v & $\mathrm{t}$ & ut & uhl & $\mathrm{T}$ \\
\hline
\end{tabular}


Tab. 3: Characteristics of eco-climate noted at meteorological station Jablanica.

\begin{tabular}{|c|c|c|c|c|c|c|c|c|c|c|c|c|c|}
\hline \multicolumn{14}{|c|}{ Meteorological Station: JABLANICA (202 m) } \\
\hline Month & $I$ & II & III & IV & $V$ & VI & VII & VIII & $I X$ & $x$ & $X I$ & $X I I$ & $\begin{array}{l}\text { Average } \\
\text { annual value }\end{array}$ \\
\hline Precipitation (mm) & 177 & 171 & 167 & 161 & 107 & 104 & 64 & 101 & 101 & 184 & 342 & 366 & 2.045 \\
\hline Temperature $\left({ }^{\circ} \mathrm{C}\right)$ & 1.5 & 3.4 & 7.4 & 12.6 & 16.5 & 19.7 & 21.8 & 21.5 & 18.1 & 13.2 & 9.5 & 3 & 12.4 \\
\hline RF m (Gračanin) & 118 & 50 & 22.56 & 12.8 & 6.48 & 5.28 & 2.93 & 4.69 & 5.58 & 13.93 & 36 & 122 & 164.92 \\
\hline Humidity & ph & ph & $\mathrm{ph}$ & $\mathrm{h}$ & sh & sh & a & sa & sh & $\mathrm{ph}$ & $\mathrm{ph}$ & ph & ph \\
\hline $\begin{array}{l}\text { Warm character of } \\
\text { ecoclimate }\end{array}$ & $\mathrm{hl}$ & $\mathrm{hl}$ & uhl & $t$ & $t$ & $\mathrm{t}$ & v & v & $t$ & $t$ & ut & hl & $t$ \\
\hline
\end{tabular}

Tab. 4: Characteristics of ecoclimate noted at meteorological station Konjic.

\begin{tabular}{|c|c|c|c|c|c|c|c|c|c|c|c|c|c|}
\hline \multicolumn{14}{|c|}{ Meteorological Station: KONJIC (277 m) } \\
\hline Month & $I$ & II & III & IV & $V$ & VI & VII & VIII & IX & $x$ & $X I$ & $X I I$ & $\begin{array}{l}\text { Average } \\
\text { annual value }\end{array}$ \\
\hline Precipitation $(\mathrm{mm})$ & 141 & 177 & 96 & 102 & 102 & 76 & 58 & 54 & 104 & 134 & 198 & 222 & 1.464 \\
\hline Temperature $\left({ }^{\circ} \mathrm{C}\right)$ & 0.5 & 2.4 & 6.1 & 10.9 & 15.4 & 18.5 & 19.8 & 20.1 & 16.7 & 12 & 8 & 3 & 11.1 \\
\hline RF m (Gračanin) & 282 & 74 & 15.73 & 9.35 & 6.62 & 4.11 & 2.93 & 2.68 & 6.22 & 11.16 & 24.8 & 74 & 131.89 \\
\hline Humidity & $\mathrm{ph}$ & $\mathrm{ph}$ & $\mathrm{ph}$ & $\mathrm{h}$ & sh & sa & a & a & sh & $\mathrm{h}$ & ph & $\mathrm{ph}$ & ph \\
\hline $\begin{array}{l}\text { Warm character of } \\
\text { ecoclimate }\end{array}$ & $\mathrm{hl}$ & hl & uhl & ut & $\mathrm{t}$ & $\mathrm{t}$ & $\mathrm{t}$ & $v$ & $\mathrm{t}$ & ut & uhl & hl & ut \\
\hline
\end{tabular}

lous meadows from the class Festuco-Brometea Br.-Bl. \& Tx. 1943, as well as rock debris communities on limestone from the class Thero-Brachypodietea Br.-Bl. 1947.

Summarized characteristics of humidity and temperature are given in Tabs. 1-4, after records from meteorological stations which are to be found in the investigated area. Although the precipitation rate noted at majority of meteorological stations is very high (maritime type), the ecoclimate is considered to be arid (dry) in some periods of year, which results in the occurrence of typical karst flora and vegetation.

Plant cover in karst regions is strongly determined by wind. In karstic habitats, especially of southern and western aspects, formative power of wind comes to its full expression. In habitats that are more protected from wind a luxuriant vegetation of karst woods with whitebarked pine Amphoricarpi-Pinetum leucodermis develops Fukarek 1966, and even cold woods with spruce and fir Abieti-Piceetum illyricum Stef. 1963, which is a true rarity in the Dinaric karst region. While southern and south-western slopes of Čvrsnica mountain are covered by low woods and thickets, its northern slopes are covered by luxuriant woods that are considered to be a true natural reserve, such as Masna Luka.

\section{SOIL}

In this area different types of soil occur, which were induced by specific climate types, geological base, wind and other ecological factors. On carbonate bedrock diverse development series of soil occur. Beginning with the undeveloped ones, these soils are: litosol (rocky type of soil), regosol (on broken rocks), black earth on limestone or calcomelanosol, rendzine, whereas on less steep slopes occurs brown earth on limestone or calcocambisol. In some places, over flat ground, also ilimerised soil type or luvisol occurs. The hydromorphous soils occur only on river banks of small watercourses, such is the case with planohistosol (alkaline bogs), and gley or eugley which occur along large water bodies, such as alluvium or fluvisol.

On bare carbonate bedrock lithosol prevails. This is a shallow type of soil, often of less than $1 \mathrm{~mm}$ deep. Similar type of soil is regosol, but it occurs only on broken rocks, often in rock fissures of large carbonate blocks. This soil type has got undeveloped humus-accumulative horizont, of (A)-C profile.

Despite being shallow and poor in nutritient, this soil is overgrown mostly by endemic and relict plants which constitute numerous endemo-relict communities in rock crevices belonging to vegetation orders Amphoricarpetalia Lakušić 1968, Moltkeetalia petraeae Lakušić 1968 and Potentilletalia caulescentis Br.-Bl. 1926, as well as communities on screes from orders Arabidetalia flavescentis Lakušić 1968 and Drypeetalia spinosae Quezel 1967.

On rendzine and calcomelanosol occur broadleaved-deciduous woods and thickets belonging to or- 
ders Ostryo-Carpinetalia orientalis Lakušić, Pavlović \& Redžić 1982, Quercetalia pubescentis Br.-Bl. (1931) 1932 and Fagetalia Pawl. 1928, and rocky grasslands from orders Scorzonero-Chrysopogonetalia Horvatić \& Horvat (1956) 1958, Koelerietalia splendentis Horvatić 1975 and thermophyllous meadows from order Brometalia erecti (W. Koch 1926) Br.-Bl. 1936. On these soils (if more organic by nature) in sub-alpine and alpine belt prevail grasslands on carbonate foundation encompassed by orders Seslerietalia juncifoliae Horvat 1930, Crepidetalia dinarice Lakušić 1966 and Edraiantho-Seslerietalia Redžić 2003, while around snowbeds vegetation order Salicetalia retusae-serpyllifoliae Lakušić et al. 1979 occurs.

Brown earth on limestone, so called calcocambisol, is associated with mild slopes and woods of white-barked pine combined with black pine belonging to order Pinetalia heldrechii-nigrae Lakušić 1972, as well as beech woods of Fagetalia Pawl. 1928 order, and temperatehumid meadows belonging to order Arrhenatheretalia Pawl. 1928 (Redžić et al. 2007).

Inspite of karstic terrain, in some places occur swampy and boggy types of soil (planohistosol), such is the case in Masna Luka, Blidinje (on Čvrsnica mountain) and Boračko lake, and on Prenj mountain. In the valley of the Neretva river and its affluents colluvium and fluvisol occur frequently, with relict plant communities of grey willow and sage Petterio-Salicetum incanae Redžić et al. 1992-94).

\section{MATERIAL AND METHODS}

\section{APPROACH AND MISSION}

The main parameter in this assessment was the biodiversity (diversity), as understood by the most recent International Community beliefs OUN - AGENDA 21, Rio de Janeiro 1992. (Sitarz 1993), and in the scope of new achievements of modern science, especially those of conservation biology and ecology. Besides, we assessed all the elements which are required to determine both forms and levels of biodiversity, like orography, geological and pedological framework, ecoclimate and anthropogenous impact reflected through diverse human activities.

\section{FIELD METHODS}

The field research on spatial and temporal biodiversity organisation, as well as on both geomorphological and hydrological features of endemic centre Prenj, Čvrsnica, Čabulja mountains, was conducted in 2007 and 2008 throughout several seasons (early spring, summer, and early autumn). Apart from data collected during this research, there have we also used data obtained in previously conducted field investigations or expert excursions accomplished by some team members. Many localities on both longitudinal and transversal profile of each mountain belonging to endemic centre of Prenj, Čvrsnica and Čabulja mountains were been analised (Figs. 2 \& 3). Each locality was precisely positioned by GPS, as it is shown on the map.

\section{ASSESSMENT OF FLORISTIC AND VEGETATION DIVERSITY}

The assessment of floristic diversity of macrophytes (vascular plants) was carried out on previously cho- sen transects, one longitudinal and several transversal profiles, of Prenj, Čvrsnica and Čabulja mountains, as well as on a great number of spots along field margins, respectively. It was determined the representative area size, which is the space in which all plants were identified.

Apart from that, herbal material was gathered in the field and properly preserved and determined afterwards by usage of relevant botanical keys, from both local and international floristic literature (Hayek 1927-1933; Tutin et al. 1964-1980; Beck et al. 1983; Oberdorfer 1983).

The analysis of plant communities and vegetation diversity were carried out on exceptionally large number of points (Figs. 2 \& 3), in all ecosystem types of endemic centre of Prenj, Čvrsnica and Čabulja mountains. The size of analised plots was $100 \mathrm{~m}^{2}$ (for non-forest community types), respectively, 200 and $500 \mathrm{~m}^{2}$, if forest ecosystem was concerned. Each plot was analysed in terms of abundance and coverage, as well as of sociabilty and vitality assessment for each of detected species. The Braun-Blanquet methodology was applied, or methodology of Zurich-Montpelier's School, which is generally accepted for all kinds of vegetation biodiversity studies (Braun-Blanquet 1964).

Formulating of definition and concept of basic vegetational units - syntaxa were carried out in accordance with the "International Code of Phytosociological Nomenclature" (Webber et al. 2000). After this Code, vegetation is organised in associations (basic unit), alliances (comprising more kindred associations), orders (comprising more kindred alliances) and classes (comprising more both floristically and ecologically kindred orders). 


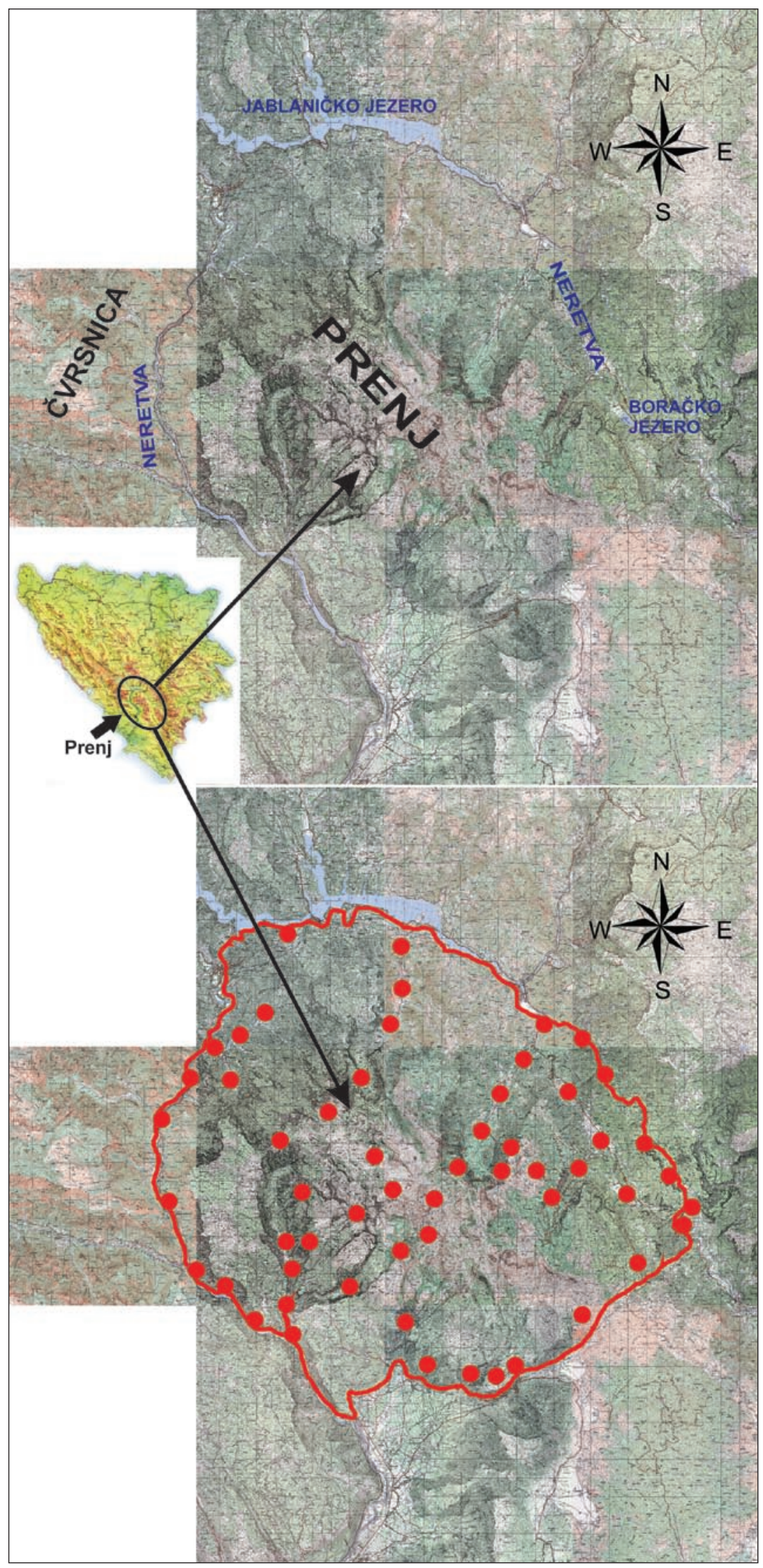

Fig. 2: The area of Prenj mountain with main localities where biological and geomorphological diversity were analised.

Beside the standard methodology for the assessment of diversity in terms of species and ecology (Magurran 1988; Scheiner 1992), the methodology for the assessment of syntaxonomic diversity as an indicator for vegetation and floristic diversity was applied (Redžić 2007c, 2007d, 2008b).

Each of the organisation units has got its own suffix. The nomenclature of vegetation units is given after "Prodromus biljnih zajednica BiH" (Lakušić et al. 1978), "Prodomus phytocoenosum Jugoslaviae ad mappam vegetation M 1: 200 000" (Jovanović et al. 1986) and "The Diversity of European Vegetation" (Rodwell et al. 2002). When it comes to interpretation of vegetation diversity, apart from previously recognized communities the newly discovered communities, which were provisionaly described after regulation of the Code of phytocoenological nomenclature, were also taken into account (Webber et al. 2000).

The intention of the paper is not to describe such communities in detail, but to use them as a bioindicator for karstic biodiversity. Those communities will be fully phytocoenological interpreted in our next syntaxonomical communication. In the following text they are marked with an asterisk $\left(^{*}\right)$.

\section{ANALYSIS AND DIGITISING OF DATA BY GIS METHODOLOGY}

The largest share of vegetation units was interpreted on maps in scale 1: 25000 . For the spatial analysis and cartographic interpretation of records obtained in the field, ArcView programme package version 3.2. was applied, whereby as a cartographic background 1: 25000 maps were used. The 


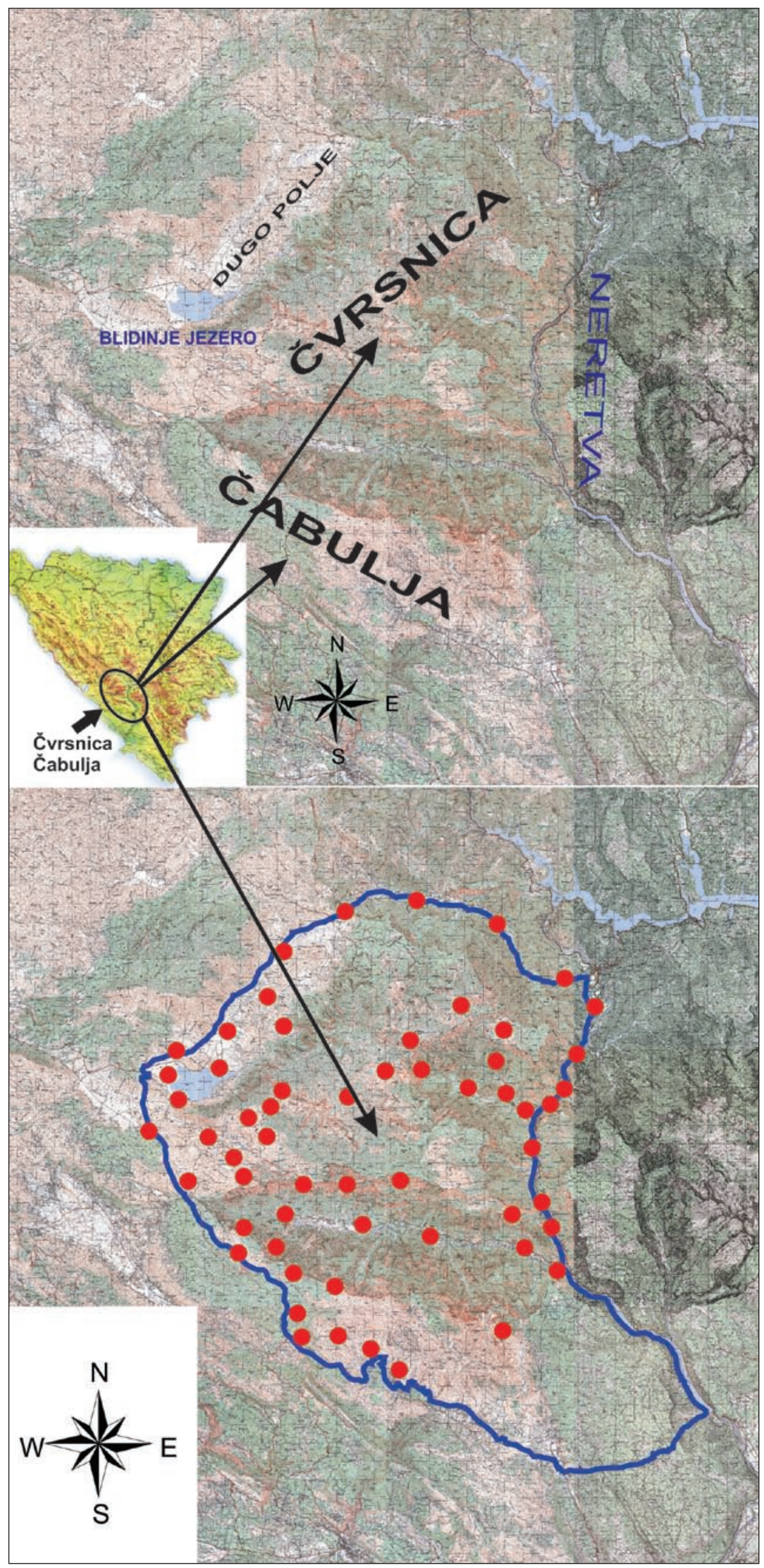

Fig. 3: The area of Črrsnica and Čabulja mountains with main localities where biological and geomorphological diversity were analised.

analysis was carried out on the base of vast material collected during either recent or previous field research (including co-ordinates and records from the field maps).

During the field work well documented and described records were included into the GIS database, which encompasses information on distribution of abiotic and biotic components in the investigated area (Tab. 5). Hence, the GIS database contains a series of spatial records on both abiotic and biotic component in the investigated area. Information on quantity, distribution and status of plant communities were also imported into the database and linked with the appropriate GIS layer (Ashdown \& Schaller 1990). The spatial analysis of GIS records enabled the identification of areas with high ecological and biological value. 
Tab. 5: GIS records sets.

\begin{tabular}{l|l|l|l}
\hline GIS data set & Description & Type of feature & Scale \\
\hline Position & Position of the investigated area given on the map in scale 1:25 000 & topographic maps & $1: 25000$ \\
\hline Geology & Geological foundation layers taken from the geological map in scale 1:100 000 & polygon & $1: 100000$ \\
\hline Vegetation & $\begin{array}{l}\text { Location for each investigated vegetation class given on the base of literature } \\
\text { records }\end{array}$ & polygon & $1: 25000$ \\
\hline Biodiversity & $\begin{array}{l}\text { Analysis of zones with high biodiversity's level carried out on the base of } \\
\text { records contained in the database }\end{array}$ & polygon & $1: 25000$ \\
\hline
\end{tabular}

\section{RESULTS AND DISCUSSION}

\section{DIVERSITY OF VASCULAR PLANTS}

The biodiversity of vascular flora in the mountain complex that surrounds Neretva river (Prenj, Čvrsnica and Čabulja mountains.) is extremely rich (Riter-Studnička 1956; Lakušić 1973; Lakušić et al. 1982; Beck et al. 1983; Šilić 1984, Redžić et al. 2007). Out of almost 5,000 taxa, as it is estimated to occur on the territory of Bosnia and Herzegovina, there are around 2,500 taxa found in this area (Redžić 2009).

In spite of some previously undertaken floristic investigations, the biodiversity level is relatively unknown.

Besides, the area of endemic centre Prenj, Čvrsnica and Čabulja mountains is unique and hardly repeatable on bigger scale as far as the number of endemic taxa is concerned. Out of 450 endemic taxa, as it is estimated to occur in Bosnia and Herzegovina, nearly 50\% dwells in this area (Bjelčić 1987; Redžić et al. 2008). Therefore, the area of Prenj, Čvrsnica and Čabulja mountains is designated as a specific "hot spot" in respect to its floristic richness, as well as the level of endemism. It is one of the most important endemic development centres in Balkan Peninsula, and one of the largest in the Mediterranean and SE Europe, which is the reason why it is considered as the area of global value (Bjelčić \& Šilić 1971; Redžić et al. 2008).

Beside wider distributed species, there is a significant number of species belonging to alpine floral element that link this area with the Alps (Redžić 1999, 2003). On the foot of the mountains and in the canyon of Neretva river a significant number of plants belonging to Mediterranean floral element occur, which in floristic respect connects this area with the Mediterranean region. A great number of Illyrian, dinaric and Balkan floral elements found their refuge within this area. Besides, some species, that are characteristic exclusively for this endemic development centre, have also been found (Šilić 1970; Bjelčić \& Šilić 1971).

There are more than 170 both species and subspecies which were recognized as significant geo-fund en- compassed by the Park of nature "Blidinje" (Šilić 2002). From the standpoint of systematic belonging, species of following families prevail: Compositae, Caryophyllaceae, Fabaceae, Scrophulariaceae, Lamiaceae, Rosaceae, and others. The proportion of plant families in the vegetation of this area are correlated with the proportion of plant families in the flora of Bosnia and Herzegovina (Redžić et al. 2007, 2008). The most recent research of flora in the karstic part of Bosnia and Herzegovina's Dinaric Alps indicates that within this mountain complex live more than 500 species of vascular plants that are considered to be endemic-relict (Redžić 2009). This high level of endemism of vascular flora correlates with significant extent of the high level of syntaxonomic diversity, which reflects the uniqueness of karstic habitats in the most appropriate way.

\section{PHYTOGEOGRAPHY}

From biogeographical point of view the area of endemic development centre which is to be found within mountain complex of Prenj, Čvrsnica and Čabulja has a very unique position (Fukarek 1949, 1965; Lakušić 1969, 1981; Bjelčić \& Šilić 1971; Redžić \& Dizdarević 1998; Šilić 2000; Redžić 2004). This is the area where two large phytogeographic regions collide: (i) Euro Siberian - North American and (ii) Alpine - high Nordic region. Besides, there is strong influence coming from the Mediterranean region in south.

EUROSIBERIAN - NORTH AMERICAN REGION extends across the largest portion of the endemic development centre. It includes a broad belt from the lowest sub-montane area to upper timberline. In the investigated area, the region is divided into three lower phytogeographic units, so called, provinces: (i) Illyrian, (ii) Moesian and (iii) Province of relict black pine forests.

Illyrian province on both horizontal and vertical profile of endemic centre of Prenj, Čvrsnica and Čabulja 
mountains is differentiated into the following vegetation belts or sub-belts: (i) Xero-thermophyllous deciduous forests and thickets of pubescent oak, Turkey oak and Italian oak belonging to order Quercetalia pubescentis Br.-Bl. (1931) 1932, in supra-Mediterranean belt; (ii) Xero-thermophyllous deciduous lower forests and thickets of oriental hornbeam belonging to order Ostryo - Carpinetalia orientalis Lakušić, Pavlović \& Redžić 1982 (alliance Carpinion orientalis Blečić \& Lakušić 1966); (iii) Xero-thermophyllous deciduous forests and thickets of hope hornbeam belonging to order Ostryo - Carpinetalia orientalis Lakušić, Pavlović \& Redžić 1982 (alliance Seslerio-Ostryon Lakušić, Pavlović \& Redžić 1982); (iv) Temperate humid sessile oak - hornbeam forests (alliance Carpinion betuli Oberd. 1953); (v) Beech forests belonging to order Fagetalia sylvaticae Pawl. 1928 (alliance Fagion moesiacae Blečić \& Lakušić 1970 and AremonioFagion Török et al. 1989) (vi) Dark coniferous forests of spruce and fir (alliance Vaccinio - Piceion Br.-Bl. 1938) and (vii) Low thickets of mountain pine (alliance Pinion mugi Pawl. 1928 "Illyricum").

Beech forests belonging to order Fagetalia sylvaticae Pawl. 1928 (alliance Fagion moesiacae Blečić \& Lakušić 1970 and Aremonio-Fagion Török et al. 1989) are very diverse and include: (i) Montane temperate humid beech forests (association Fagetum silvaticae montanum Horvat 1938); (ii) Thermophyllous beech forests (alliance Seslerio-Fagion sylvaticae Redžić \& Barudanović 2010); (iii) Thermophyllous forests of beech and Acer obtusatum Waldst. \& Kit. ex Willd. (association Aceri obtusati-Fagetum Fabijanić, Fukarek \& Stefanović ex Fukarek, Stefanović \& Fabijanić 1967; (iv) Upland mixed woods with beech and fir (association Abieti - Fagetum (Fukarek \& Stefanović) Fukarek 1969); (v) Mediterranean montane beech forests (association Fagetum "mediteraneomontanum" Redžić et al. 1984); (vi) Sub-alpine beech forests (association Aceri - Fagetum moesiacae "subalpinum" Fukarek \& Stefanović 1958).

Moesian province extends across the warmer share of the area, on horizontal and vertical profile. These are mainly canyons and steep slopes with southern aspect. The territory of Moesian province is differentiated into vegetation belts and sub-belts as follows: (i) Xeric forests of Italian oak (alliance Quercion confertae Horvat 1958 ) (ii) Meso-thermophyllous forests of sessile oak (alliance Quercion robori-petraeae Br.-Bl. 1931) (iii) Beech forests belonging to order Fagetalia Pawl. 1928 (alliance Fagion moesiacae Blečić \& Lakušić 1970).

Beech forests include: (i) montane beech forests (association Fagetum moesiacae "montanum" Blečić \& Lakušić 1970); (ii) Thermophyllous forests of Moesian beech and autumn moor grass (association SeslerioFagetum moesiacae Blečić \& Lakušić 1970); (iii) Thermo- phyllous forests of Moesian beech and Acer obtusatum Waldst. \& Kit. ex Willd. (association Aceri obtusati - Fagetum moesiacae Fabijanić, Fukarek \& Stefanović 1963); (iv) Upland forests of Moesian beech and fir (association Abieti - Fagetum moesiacae Blečić \& Lakušić 1970) and (v) Sub-alpine forests of Moesian beech (association Aceri - Fagetum moesiacae subalpinum Fukarek \& Stefanović 1958). Woods of Moesian beech often alternate with woods of white-barked pine, or mountain pine thickets Pinetum mugi that makes here the upper timberline.

Province of relict black pine forests extends across the area with endemic white-barked pine Pinus heldreichii $\mathrm{H}$. Christ and Illyrian black pine pine (Pinus nigra J.F.Arnold susp. austriaca (Hoss) Bid.). In terms of its ecology and territory, the province is differentiated into several clearly divided phytogeographic sectors: (i) Forests of Illyrian black pine on dolomites belonging to alliance Pinion austriacae Horvat 1959 (ii) Forests of Illyrian black pine of sub-alliance Orno - Ericenion "dolomiticum" Horvat 1959 (iii) Community with Illyrian black pine in crevices of carboniferous rocks (Onosmo - Pinetum "illyricum"*) and (iv) Forests of white-barked pine belonging to alliance Pinion heldreichii Horvat 1950.

Forests of alliance Pinion heldreichii Horvat 1950 are endemic-relic and typical for this part of Dinaric karst. This alliance includes endemic communities: (i) Mediterranean - montane forests of white-barked pine of association Pinetum heldreichii "mediterraneo - montanum" Blečić \& Lakušić 1969; (ii) Upland forests of whitebarked pine and spruce ass. Piceo - Pinetum heldreichii Lakušić; (iii) Upland forests of beech and white-barked pine ass. Fago - Pinetum heldreichii Janković (1972) 1975 (iii) Montane forests of white-barked pine ass. Pinetum heldreichii "subalpinum" Fukarek 1967 and (iv) Association with white-barked pine in crevices of carboniferous rocks Amphoricarpo-Pinetum heldreichii Fukarek 1967.

ALPINE - HIGH NORDIC REGION continues in ecological sense on sub-alpine belt of Euro Siberian North American region. It encompasses the area of high mountain peaks, above upper timberline, mostly with mountain pine communities Pinetum mugi Lakušić 1977 s.lat., and in some cases above low forests of white-barked pine Pinetum heldreichii "subalpinum" Fukarek 1967, or above sub-alpine forests of beech Fagetum "subalpinum" "dinaricum" Tregubov 1957. Here, this region is represented by province of high Dinaric Alps. On a vertical profile this province is differentiated into three belts: (i) Discontinued belt of sub-nivale vegetation around snow beds on carboniferous ground (alliance Salicion retusae Horvat 1949 in Horvat, Glavač \& Ellenberg 1974) and (ii) Alpine grasslands or high alpine "tundra". 
Alpine and sub-alpine pastures or high mountains tundra include those communities: (i) Alpine grasslands on the highest places exposed to strong winds with narrow leaved moor grass (alliance Seslerion juncifoliae Horvat 1930) (ii) Alpine grasslands on the highest places with dinaric alliance Oxytropidion dinaricae Lakušić 1966 (iii) Alpine grasslands on the highest places with Prenj's alliance Oxytropidion prenjae $e^{*}$ and (iv) Alpine grasslands in sheltered places (alliance Festucion bosniacae Horvat 1930 corr. Redžić 2007). Sub-alpine grasslands (often of secondary character) include: (i) Sub-alpine grasslands in exposed habitats alliance Seslerion robustae (Lakušić et al. 1982) Redžić 2003 and (ii) Sub-alpine grasslands in sheltered places Stachydi-Festucenion bosniacae*.

Due to numerous floristic and vegetation specificities, the province of high Dinaric Alps in this area is represented by high Prenj's sector. This phytogeographic sector includes mountains of the endemic development centre of Prenj, Čvrsnica and Čabulja, and large proportion of Velež mountain. This sector is characterized by a great number of endemic species: Minuartia handelii Mattf., Campanula hercegovina Degen \& Fiala, Asperula hercegovina Degen, Arenaria gracilis Waldst. \& Kit., Am- phoricarpos autariatus Blečić \& E.Mayer, Dianthus prenjus Beck, Euphorbia hercegovina Beck, Dianthus freynii Vandas, Saxifraga prenja Beck, Edraianthus hercegovinus K.Malý, Oxytropis prenja (Beck) Beck, and others. All enlisted, as well as many other species in this area, constitute around 250 associations, out of which significant number is of endemic or steno-endemic character (see syntaxonomic overview of associations) that provides remarkable and unique features to this area.

\section{DIVERSITY OF HABITATS AND VEGETATION}

The area of endemic centre Prenj, Čvrsnica and Čabulja is highly diversified in terms of vegetation or ecological diversity. On this, in respect of abiogen, heterogeneous space, 236 ecological units of association level occur, encompassed by several ecological floristic systems of alliance level (116) and 63 orders, and as much as 34 vegetation classes.

Vegetation of cliffs and rocks (Asplenietea trichomanis Br.-Bl. 1934 corr. Oberd. 1977)

Even though they are on the lowest level of ecologi-

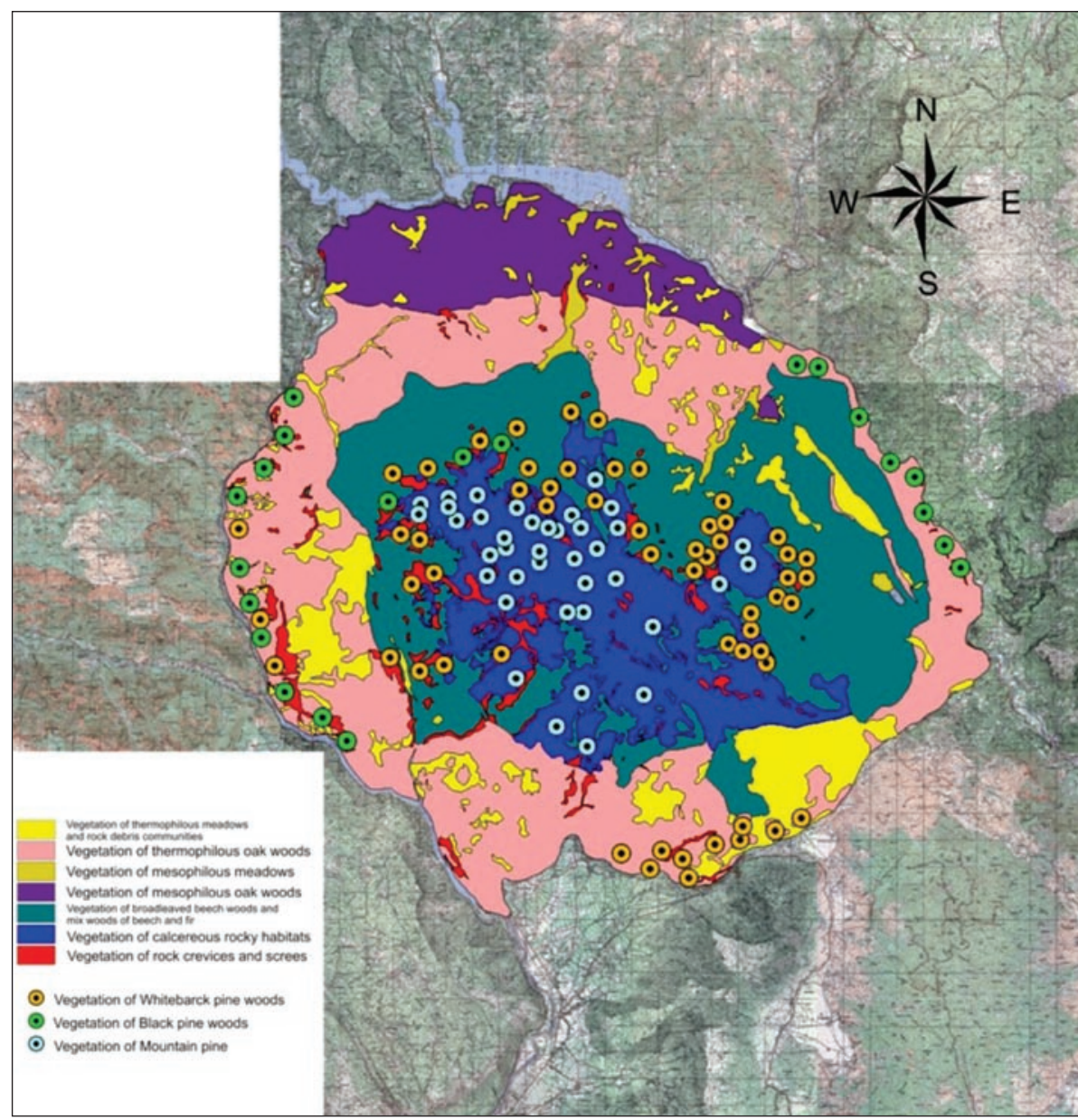

cal integration, these ecosystems are very present in the investigated area. Communities of these particular ecosystems give the strongest proof of uniqueness and singularity of this area. Unlike many others, ecosystems of cracks in the rock are developed at the whole vertical profile (between $250 \mathrm{~m}$ and 2,220 m) of endemic development centre. As they appear in all vegetation zones, they are undoubtedly intrazonal in character. Therefore, besides their own differential peculiarity, they also have additional characteristics that are caused by zonal or climate - regional ecosystems they have developed in. other ecosystems at vertical profile.

Fig. 4: Cartographic overview of main types of vegetation in area of mountain Prenj. 
Basic determination of this vegetation is carbonate geological surface (limestone, dolomites and dolomitic limestone) at the whole vertical profile, with very distinguished inclination of terrain (between $50-90^{\circ}$ ), sometimes even $120^{\circ}$ (in recess of rocks), extremely shallow soil - kalkolithosol, and on shattering rocks - kalkoregosol. These terrains are very shallow (between several millimetres and several centimetres). They are rich in mechanical composition, while they are extremely poor in nutritive (organic) substances. Eco-climate is very variable, from somewhat altered Mediterranean and sub-Mediterranean in canyon of Neretva river to mountain climate in Alpine belt of Prenj, Čvrsnica and Čabulja. Extremely high variability of basic eco-climate parameters - temperature, relative air humidity and ecologically available water, as well as nutritive poorness, are one of the main factors that determined specific templates of speciation (development of species), endemicgenesis (development of endemic plants) and syngenesis (development of plant communities). The best example of specific development patterns for endemic plants on bare karst represent rock crevices which was the reason

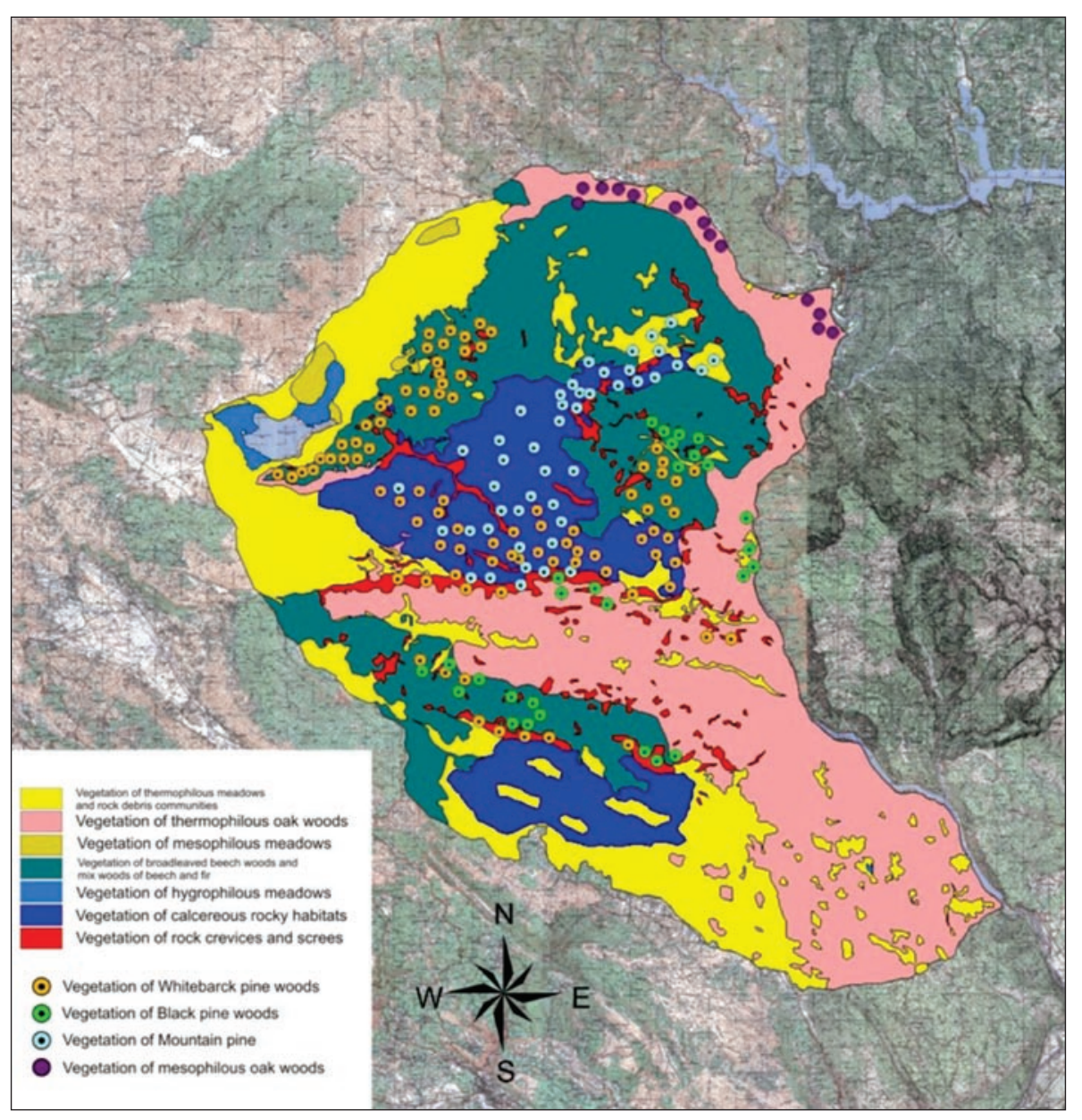

why the development endemic centre was created right in this area.

Within the ecosystem in cracks of calcareous rocks, at this area, determined are 30 communities at level of association, 10 on level of alliances, 5 on level of order, and they all belong to the class Asplenitea trichomanis $\mathrm{Br}$.- $\mathrm{Bl}$. 1934 corr. Oberd. 1977. All communities in canyon of Neretva river and its confluents are endemic and Tertiary - relict character, while some are of glacial - relict character in sub-Alpine and Alpine area such as communities of alliance Amphoricarpion autariati Lakušić 1968, Amphoricarpion neumayeri Lakušić 1968, Micromerion croaticae Horvat 1931 and Potenillion caulescentis Br.Bl. 1926). Communities of this vegetation contain more than 200 different taxa, out of which most are of endemic and steno-endemic character. Especially rich in endemic species is community of Heliospermo retzdorfiani-Oreoherzogietum illyricae Šilić 1970 . Some of them are exclusively connected to endemic centre (Campanula hercegovina Degen, Salix glabra Scop. var. deylii Röhl, Silene retzdorffiana (K.Malý) H.Neumayer (Syn.: Heliosperma retzdorffiana K.Malý), Rhamnus illyrica Gris. ap. Pant., Sibiraea croatica Degen (Syn.: Sibiraea altaiensis (Laxm.) C.K.Schneid. var. croatica (Degen) Beck/, Potentilla speciosa Willd. and others). In syntaxonomical sense, this class is differentiated into following orders, alliances and associations. Order: Potentilletalia caulescentis Br.-Bl. 1926 include alliances of $\mathrm{Po}$ tentillion caulescentis $\mathrm{Br}$.-Bl. 1926 and community of $\mathrm{Po}$ tentilletum caulescentis (Br.Bl. 1926) Aich. 1933, in the coldest places of north facing slopes in the alpine belt, and shaded carbonate overhangs. This order includes communities that continue on alpine communities of carbonate rock crevices of the north-

Fig. 5: Cartographic overview of main types of vegetation in area of mountains Črrsnica and $\check{C} a$ bulja. 
western Dinaric Alps belonging to alliance Micromerion croaticae Horvat 1931 which is differentiated into several endemo-relict communites, such as: Potentilletum clusianae Horvat 1931, Asplenietum fissi Horvat 1931, Asperulo hercegovinae-Potentilletum appeninae*, Arenario gracilisCampanuletum hercegovinae*, Primulo-Edraianthetum serpyllifoliae*, Primulo-Campanuletum hercegovinae*, Asplenio fissi-Potentilletum apenninanae ${ }^{\star}$ and Edraiantho serpyllifolii-Potentilletum clusianae*. Vegetation in crack rocks of shaded places is encompassed by the alpine alliance Cystopteridion Richard 1972 and Moehringion muscosae Horvat \& Horvatić 1951, whose most significant communities in hilly and upland belt is MoehringioCorydaletum leiospermae ${ }^{*}$, while in the sub-alpine belt occur endemic communitiy Cardamino-Campanuletum cochlearifoliae*.

Due to strong impact of maritime climate which affects the southern and southeastern slopes of this mountain complex, in the rock crevices occur also communities that characterize the vegetation of carbonate rock fissures of the litoral southeastern Dinaric Alps. In respect to vegetation, these communities are encompassed by the endemic order Moltkietalia petraeae Lakušić 1968 with two alliances: Centaureo-Campanulion Horvatić 1934 in the hotest habitats of both supra-Mediterranean and hilly belt, and Edraianthion tenuifolii Lakušić 1968 in warm, dolomite habitats of continental area. The alliance Centaureo-Campanulion Horvatic 1934 is very diversified in this area. It includes several endemo-relict communities, of which the most important are: Inulo verbascifoliae-Moltkietum petraeae ${ }^{*}$, Asplenio-Cotyledonetum horizontalis Horvatić 1963, Cephalario leucanthaeInuletum verbascifoliae*, Achnathero-Moltkaeetum petraeae $^{*}$, Micromerio thymifoliae-Inuletum verbascifoliae and Edraiantho-Seslerietum interruptae Redžić 1990. The alliance Edraianthion tenuifolii Lakušić 1968 includes the highest positions of endemo-relict communities with Moltkia within its distribution range (around 1,700 $\mathrm{m}$ above sea level- Borašnica on Prenj mountain). The most important communities are: Potentilla speciosaMoltkia petraea Horvat 1941 and Centaureo triumfettiMoltkietum petraeae*.

The vegetation of rock cracks in the sub-alpine and alpine belt in major share of the investigated karst area belongs to south-dinaric order Amphoricarpetalia Lakušić 1968, which is being differentiated in two alliances: Amphoricarpion autariati Lakušić 1968 in the canyon of Neretva river with following communities: Heliospermo retzdorfiani-Oreoherzogietum illyricae Šilić 1970 and Micromerio croaticae-Potentilletum persicinae*. The alliance Amphoricarpion neumayeri Lakušić 1968 encompasses communities of limestone and dolomite rock crevices in the zone of endemic white-barked pine. The most significant are: Amphoricarpi-Pinetum leucodermis Fukarek 1966, Moltkio-Pinetum heldreichii*, Arenario gracili-Moltkietum petraeae* and Asperulo hercegovinaePotentilletum persicinae

High value to the area is provided also by small fragments of communities which are characteristic for shaded mediterranean carbonate rocks belonging to order Anomodonto-Polypodietalia O. de Bolòs \& J. Vives 1957 and alliance Polypodion serrati Br.-Bl. (1931) 1947. Vegetation of crevices of dolomitized limestone rocks in the zone of white-barked pine belongs to order Potentilletalia speciosae Quézel 1964 and separated endemic alliance Moltkio-Potentillion speciosae ${ }^{\star}$ with two alliances: Edraiantho-Potentilletum speciosae* and Molkaeo-Potentilletum speciosae*.

These ecosystems are very affine to ecosystems of shaded and wet rocks of Mediterranean and sub-Mediterranean belt of class Adiantetea Br.-Bl. 1947, order Adiantetalia Br.-Bl. 1931 and alliance Adiantion capilliveneris Br.-Bl. 1931, which is developed in fragments on recesses in canyon of river Neretva that is under influence of Mediterranean climate. They spread on very small surfaces of this area, but they have huge ecological and biological meaning.

Vegetation in ecosystems of on carbonate screes (Thlaspietea rotundifolii Br.-Bl. 1948)

Same as ecosystems of cracks in the rocks, carbonate screes or grinders are azonal in character. They are developed in bases of mountain massive, and all the way to peaks of Prenj, Čvrsnica and Čabulja.They are especially impressive in sub-mountain belt of the whole endemic centre where they form magnificent communities of unique floristic content, appearance, origin and role in system of creation of new types of vegetation, or in system of syngenesis. Main features of these ecosystems are given by vegetation that is adjusted to extreme ecological conditions, constant movement of geological surface, very shallow soils (sirozem), then colluviums in bases, very variable ecoclimate characteristics (specially temperature, relative air humidity and water available to plants). Plants that are part of construction of vegetation of rock creeps have adjusted to these conditions during evolution, so they have developed very deep and often very branched system of roots, pillow-like bush forms and relatively small surface biomass. Due to extreme and unique of climate forms, geological surface, lack of organic substances and other factors of biotope, specific forms of speciation have developed that are characterized by unique endemic genesis. That resulted in development of endemics, relicts and plant species with narrow geographical spreading. 
In this vegetation type 30 associations, 7 alliances, included in 4 orders that belong to wider spread class are determined. This class includes south-eastern-dinaric order: Arabidetalia flavescentis Lakušić 1968 that makes syngenetic connection with the alpine order Thlaspietalia rotundifolii $\mathrm{Br}$.-Bl. 1926, alliance Corydalion ochroleuceae Lakušić 1975 and community Micromerio thymifoliae-Corydaletum ochroleuceae ${ }^{*}$ on screes of upland and hilly belt in the canyon of Neretva river. The main share of this vegetation order is to be found within alpine and sub-alpine screes of north facing slopes of Prenj and Čvrsnica mountain All vegetation units are of endemic-relict character. Thus, endemic alliance Saxifragion prenjae Lakušić 1968 is differentiated in several communities which inhabit screes that occur at sinkhole slopes, of which the most important are: Saxifrago-Papaveretum kerneri Lakušić 1968, Violo biflorae- Saxifragetum prenjae*, Aubrietum croatiace Horvat 1931, BunioSaxifragetum prenjae ${ }^{*}$, Seslerio robustae-Scutellarietum alpinae, Cystopteri-Aquilegietum dinaricae*, Saxifrago prenjae-Adenostyletum alliariacae ${ }^{*}$, Doronico-Adenostyletum kerneri* and Papavero kerneri-Doronicetum which is continuation of communities around snow beds. On screes made of fine comminute carbonate rocks communities Bunio-Iberetum carnosae Horvat 1931 and Euphorbio-Valerianetum bertisceae Lakušić 1968 from the alliance Bunion alpini Lakušić 1968 occur.

On the entire vertical profile (from Neretva river to mountain peaks, especially those of Čabulja mountain) occur screes that are affected by Mediterranean climate and hence belong to order Drypeetalia spinosae Quézel 1967 with alliance Peltarion alliaceae Horvatić (1956) 1958, in which high richness of both species and communities was identified. The greatest significance in terms of phytogeography have communities as follows: Drypeetum jacquinianae Horvatić 1934, Geranio-Anthriscetum fumarioidis Horvatić 1963, Teucrio arduiniPeucedanetum ${ }^{*}$, Micromerio thymifoliae-Geranietum macrorrhizi*, Euphorbio-Saturejetum montanae* and Corydalo-Epilobietum rosmarinifoliae.

Dry alpine and sub-alpine screes are encompassed by the alliance Silenion marginatae Lakušić 1968 that includes following endemo-relict communities: DrypidiSilenetum marginatae Lakušić 1968, Geranio-Heracleetum balcanicum Lakušić 1968, Drypeetum linneanae Horvat 1931, Drypidi-Heracleetum orsinii ${ }^{*}$, Dryopteridetum villarsi (Jenny-Lips 1930) Horvat 1931, Seslerio robustaePetasitetum kablikiani* and Senecio visiniani-Heracleetum orsinii on limestone blocks of southern Prenj mountain slopes.

Screes along with rock crevices provide this area with unique forms of overall biodiversity. Following endemic species found refuge in this area: Saxifraga prenja
Beck, Papaver kerneri Hayek, Heracleum orsinii Guss., Teucrium arduini $\mathrm{L}$. and others.

Ecosystems of screes that occur in dry bottoms of sinking creeks are significantly different both in their structure and genesis from mountain screes. Especially important biotopes are basins of many flooding rivers, sinking creeks, and confluents of Neretva that sink during vegetation period. At these places, where main biotope attribute is represented by pebbles, endemic communities of order Epilobietalia Fleischeri Moor 1958 occur. This order includes the alliance Salicion incanae Aichinger 1933 with endemic-relict communities: Petterio-Salicetum incanae Redžić et al. 1992/94 (Muratspahić et al. 1991-1994; Redžić et al. 1992-1994), Ostryo-Salicetum incanae*, Molinio litoralis-Petasitetum kablikiani* and Salvio officinali-Salicetum incanae*. It should be stressed that such habitats are under influence of surface water flow during wet and cold period of a year. Scree communities on stone blocks in the supra-Mediterranean and hilly belt are encompassed by the Stipetum calamagrostis Br.-Bl. 1918 from the alliance Stipion calamagrostis Jenny-Lips 1930 (Achnatherion calamagrostis Jenny-Lips 1930), belonging to separate order Galio-Parietarietalia Boşcaiu et al. 1966. Many of them are of endemic character. Representative communities of that kind are to be found in valleys of Grabovica and Drežnica river.

Vegetation around snow beds on carbonate substrates (Salicetea herbaceae Br.-Bl.1947)

At many places in Alpine and sub-Alpine belt of these mountains, such as sinkholes, karst valleys, mild elevations of terrain, areas that are lee warded from strong mountain winds, snow remains for long time, while at some places it remains during a whole year. In such manner, special biotopes were formed in proximity of glaciers, inhabited by mostly glacial - relicts species of plants and animals, that, at time, developed a number of unique, mostly endemic-relict communities. At this area, vegetation in proximity of glaciers is developed on shallow organic mountain humus, which although laying on carbon geological surface, is acidified due to slow decomposition of humus substance. Besides plants, that are exclusively connected with glaciers, some species that belong to neighbouring vegetation types, such as alpine and sub-alpine pastures, are also found. Due to extreme ecological circumstances, biomass is lowest in these ecosystems. Despite that, they are extraordinary important in total image of biodiversity, not only in this area, but also in biodiversity of north hemisphere as a whole. In addition, ecosystems in proximity of glaciers are the best indicators of intensity and nature of climate alterations. Vegetation around snow beds on Prenj and 
Čvrsnica mountains. is encompassed by orders Salicetalia retusae-serpyllifoliae Lakušić et al. 1979 and alliance Salicion retusae Horvat 1949 with following glacial relict communities: Soldanelo-Salicetum retusae Horvat 1933 in Horvat, Glavac \& Ellenberg 1974, Polygono vivipariSalicetum retusae*, Gentiano tergestinae-Salicetum retusae $e^{*}$ Dryadeto-Salicetum retusae ${ }^{*}$ and Trifolio-Salicetum retusae*.

Most of communities of this vegetation are of glacial - relict origin, and they have important role in assessment of age of mountain peaks and mountain as a whole. In current conditions they have an irreplaceable role in assessment of trends in area of global changes of living conditions, especially climate.

These are biotopes of significant number of glacial species, such as: Soldanella alpine L., Trifolium noricum Wulfen, Polygonum viviparum L., Gentiana tergestina Beck, Salix retusa L., S. serpyllifolia Scop., Viola zoysii Wulfen and others.

Vegetation in ecosystems of alpine and sub alpine carbonate pastures and high mountain tundra (ElynoSeslerietea Br.-Bl. 1948)

Above highest level of forest vegetation on Prenj, Čvrsnica and Čabulja mountains there is area of high mountain pastures. That is specific form of high mountain tundra that is in a wider geographical area characterized by relative poorness of flora and small production of biomass. However, at the area of those mountains, this vegetation is very rich in species, as well as in communities. It is developed above the belt of juniper of pine woods on carbonate surface of alliance Pinion mugi Pawl. 1928, and sometimes above sub-alpine forest beech (Fagetum "subalpinum" Horvat 1938) and of White bark pine Pinetum heldreichii "subalpinum". In alpine belt, mountain pastures are of primary character. Besides, they are developed in sub-alpine belt in an area where the primary vegetation is altered, and they are of secondary character here.

Considering a significant area of mountains at this region, pastures are very present here. They are specific centres of their spreading and richness compared to the whole Dinarides. Since the Dinarids are mountains built of carbonate rocks, specific communities have developed here and in syntaxonomical sense they are included in separate class of Elyno-Seslerietea Br.-Bl. 1948. This class reaches extremely high diversity level on Prenj, Čvrsnica and Čabulja mountains. It is differentiated into 30 mostly endemic and glacial relict communities, which are encompassed by six alliances and three orders. The coldest mountain habitats of alpine pastures are included into dinaric-apennine order Seslerietalia tenuifoliae Horvat 1930 with two alliances: Seslerion tenuifoliae Horvat 1930 that encompasses communities of the highest peaks exposed to the most devastating mountain winds, such as: Laeveto-Helianthemetum alpestris Horvat 1930, Festuca pančiciana-Dianthus brevicalyx Horvat 1934, EdraianthoDryadetum octopetalae Lakušić 1968, Carici laevi-Festucetum bosniacae ${ }^{*}$ and Seslerio tenuifoliae-Arctostaphylletum uvae-ursi. Redžić et al. 1984. Plant communities that inhabit leeward places and deeper calcomelanosol are included in the alliance Festucion bosniacae Horvat 1930 which is constituted of several in floristic respect quite diverse communities: Festucetum bosniacae (Syn.: Festucetum pungentis Horvat 1930). Stachydi-Festucetum bosniacae, Lilio bosniacae-Festucetum bosniacae ${ }^{*}, A v$ enulo blavii-Festucetum bosniacae ${ }^{*}$ and Gentiano symphyandrae-Festucetum bosniacae Lakušić 1975.

In the southeast, peaks of these mountains are covered by vegetation belonging to the southeast-dinaric, high-mountainous order Crepidetalia dinaricae Lakušić 1966.

The endemic alliance Oxytropidion urumovii Lakušić 1964 (Syn.:Oxytropidion dinaricae Lakušić 1966) connects this area in phytogeographic sense with the southeastern Dinaric Alps. It includes several endemic communities, such as: Seslerietum tenuifoliae "hercegovinum" Lakušić 1969, Asperulo-Festucetum pancicianae Lakušić et al. 1973, Edraiantho-Veronicetum satureoidis Lakušić et al. 1973, Elyno-Edraianthetum serpyllifolii Lakušić 1968 and Alchemillo-Scabiosetum silenifoliae* on Čvrsnica and Prenj mountains. The highest peaks of Čvrsnica and Prenj mountains, places that are exposed to the wind, are inhabited by steno-endemic communities of alpine grasslands from the alliance Oxytropidion prenjae $e^{\star}$ which encompasses communities that cover smaller areas, such as: Minuartio handelii-Caricetum pollicensis, Oxytropidi-Dryadetum octopetalae ${ }^{*}$, Potentillo clusianaeSaxifragetum marginatae*, Potentillo apenninae-Seslerietum tenuifoliae ${ }^{*}$ and Potentilletum clusiano-apenninae*.

Most exposed habitats from littoral side of these mountains are inhabited by a form of eolian vegetation of sub-alpine grasslands of order Edraiantho-Seslerietalia robustae Redžić 2003. This alti-montane vegetation order here includes the alliance Seslerion robustae (Lakušić et al.1982) Redžić 2003 (Syn.: Seslerion nitidae Horvat 1930 ) with the following communities: Seslerietum robustae (Syn.: Seslerietum nitidae Lakušić et al. 1975), Festuco bosniacae-Seslerietum robustae*, Carici-Seslerietum robustae, Avenastro blavi-Seslerietum robustae*, Astrantio carniolicae-Seslerietum robustae*, Saturejo subspicatae-Seslerietum robustae and Antherico-Seslerietum robustae ${ }^{*}$. In the driest habitats live communities from the alliance Seslerio-Edraianthion pumilii: Carici laeviHelianthemetum balcanici Horvat 1930, Arenario- Seslerietum tenuifoliae ${ }^{*}$ and Genisto dalmaticae-Seslerietum 
tenuifoliae which makes ecological continuity with the vegetation of supra-Mediterranean rocky grasslands toward lower positions.

About 800 taxa of vascular plants participate in the community of this vegetation, out of which many are of endemic - relict character. Some of them are exclusively connected to this area, and therefore they are specific steno-endemics. Mountain and sub-mountain meadows are developed on all expositions and elevations of terrain up to 50 degrees, where they are changed into communities of either screes or rock crevices. Communities on the peaks are highly exposed to winds, and so the winds are dominant climate factor in their shaping, structuring, dynamics and syngenesis. Those communities belong to orders of Seslerietalia tenuifoliae Horvat 1930 and Crepidetalia dinaricae Lakušić 1966. At shaded biotopes are sub-mountain meadows with Bosnian fescue grass Festucion bosniacae Horvat 1930 corr. Redžić 2007, and at some areas with communities with robust sedge Seslerion robustae (Lakušić et al. 1982) Redžić 2003.

The highest positions and in sense of eco-climate most rigid areas are inhabited by high mountain vegetation, that is by its physiognomy is very similar to mountain meadows, in syntaxonomical sense belong to the class Carici rupestris-Kobresietea bellardi Ohba 1974. These communities structure ecosystems of alpine and sub-alpine pastures and dwarf shrubs. In syntaxonomical sense, on researched area this class is represented by one association, of alliance Oxytropido-Elynion Br.-Bl. 1949 and order Oxytropido-Elynetalia Oberdorfer ex Albrecht 1969.

Vegetation of thermophyllous grasslands (Festuco-Brometea Br.-Bl. \& R.Tx. in Br.-Bl. 1943)

In hill and upland belt, at biotopes of former forests and bushes, currently different thermophyllous communities of meadows and rocky grasslands are developed. Soils are shallow, mostly kalkomelanosol and rendzine, rarely kalkokambisol. Meadows are very rich in species, among which some are endemic, even of relict character. In syntaxonomical sense, they belong to the order Brometalia erecti (W. Koch 1926) Br.-Bl. 1936, alliance Bromion erecti Koch 1926, which on the researched area is represented by two communities: Bromo-Plantaginetum mediae Horvat (1931) 1949 and Bromo-Danthonietum alpinae Šugar 1972.

Vegetation of Mediterranean and supra - Mediterranean rocky grasslands and meadows (TheroBrachypodietea ramosi Br.-Bl. 1947; Syn.: CymbopogoBrachypodietea p.p.)

Going toward shallower soils and warmer biotopes, in a zone of thermophyllous forests and thicket of orders
Quercetalia pubescentis Br.-Bl. (1931) 1932 and OstryoCarpinetalia orientalis Lakušić, Pavlović \& Redžić 1982 thermophyllous communities of Mediterranean and subMediterranean bullheads and meadows are developed. These communities are very rich in species (more than 500 taxa of higher plants are in their content), among which many are of endemic character. Syntaxonomically, they are very complex and differentiated in one order, 6 alliances and 11 communities, while they are unified into one class. They are encompassed by the supra-Mediterranean order Scorzoneretalia villosae Horvatić 1975 that differentiates into four alliances. At mild slopes, frequently in larger sinkholes, on deeper carbonate soils live communities of supra-Mediterranean meadows from the alliance Scorzonerion villosae Horvatić 1949, especially on Čabulja and Prenj mountains, such as: DanthonioScorzoneretum vilosae Horvat \& Horvatić (1956) 1958 and Lilio cathaniae-Agrostetum capillaris*.

On more shallow and rocky carbonate soil, at more sloped and to the wind exposed places, the communities of rocky grasslands occur. The highest positions are taken by the alliance Chrysopogoni-Satureion Horvat \& Horvatić 1934 with communities: Scabioso-Globularietum, Saturejo-Edraianthetum Horvat 1942 and StipoSalvietum officinalis Horvatić (1956) 1958.

Going upwards on a vertical profile toward subalpine belt, this rocky grassland are continued by communities from the alliance Satureion subspicatae Horvat 1959 (Carici-Centauretum rupestris Horvat 1931 and Salvio bertoloni-Saturejetum subspicatae ${ }^{\star}$ that are ecologically connected with communities of sub-alpine grasslands. In warm dolomite habitats communities from the alliance Festucion pseudovinae Soo 1933 (Koelerio-Festucetum pseudovinae and Gentiano cruciatae- Festucetum pseudovinae ${ }^{*}$ ) occur, as well as the communities Alyssetum moelendorfiani Riter-Studnička (1956) em. 1967 and Reichardio macrophyllae-Thymetum aureopunctati* that are inevitably associated with the endemic alliance on dolomite substratum Peucedanion neumayeri RiterStudnička 1967.

At habitats that are under high influence of wind, on very shallow and rocky terrains, ecosystems of pioneer vegetation of rocky grasslands are occasionally present, with class Kelerio-Corynephoretea Klika in Klika \& Novak 1941, order Alysso-Sedetalia Tx. 1951 and alliance Alysso alyssoidis-Sedion albi Oberdorfer \& Müller 1961.

\section{Herbal tall thermophyllous vegetation (Trifolio- Geranietea Müller 1962)}

In the system of progradation, communities of bullheads and thermophyllous meadows have a tendency of traversing to communities of low forest and thermophyllous thickets. In certain development stages, they 
transfer into very dynamic type of vegetation that contain species of both meadows and forests habitats. That is how ecotones are formed - currently very important habitats where intensive processes of competition and ecological co-existence are in progress. These habitats and their vegetation are of great importance in evaluation of conditions and potential possibilities, as well as trends of given type of vegetation to original climax community. Vegetation belongs to the class of TrifolioGeranietea Müller 1962, order Origanetalia Müller 1962 with two alliances - Geranion sanguniei R. Tx. in Müller 1962 and Trifolion medii Müller 1962. This vegetation is still poorly researched in those conditions.

Vegetation of hygrophyllous and mesophyllous grasslands (Molinio-Arrhenatheretea R. Tx. 1937)

Ecosystems of hygrophyllous and temperate humid meadows on the investigated area are spread on small areas, since surface water is either not present or it is poorly available in these mountains. This type of vegetation is mostly developed on deep soils. Those are brown limestone soils kalkokambisol, meadows - luvisol, and eugley and pseudogley, on flat terrains where the level of ground water is low. On a vertical profile they are developed from bases of mountains to sub-mountain areas. In syntaxonomical sense they are very complex and depending on hydro-thermic regime and floristic composition thery are differentiated into 16 associations, 13 alliances, 7 orders, while they are all unified in the class Molinio-Arrhenatheretea R. Tx. 1937. The deepest soil of both hilly and upland belt is inhabited by mesophyllous grasslands from the order Arrhenatheretalia Pawlowski 1928, alliance Arrhenatherion elatioris Br.-Bl. 1925, which are communities Arrhenatheretum elatioris R. Tx. 1937 ononidetosum and Festucetum pratensis Lakušić et al. 1975, then alliance Festuco-Agrostion capillaris Redžić 1990 with community Festuco-Agrostetum capillaris (Horvat 1951) $1962 \mathrm{em}$. Trinajstić 1972 and alliance Cynosurion cristati Tx. 1947 with community CynosuroFestucetum rubrae Redžić 1990. The grasslands of upland and sub-alpine belt are included into the endemic dinaric alliance Pancicion serbicae Lakušić 1966, of which on Prenj mountain identified are following communities: Lilio bosniacae-Crepidetum conyzifoliae*, Knautio-Festucetum nigraescentis ${ }^{*}$ and Onobrychydi-Festucetum nigraescentis $^{*}$. On humid type of soil and gently sloped terrain, which is often the case at Blidinje and Borackko lake, there is an occurance of hygrophyllous grassland communities from the order Holoschoenetalia Br.-Bl. (1931) 1947 and fragments of the community Deschampsietum mediae Br.-Bl. 1931 belonging to the alliance Deschampsion mediae Br.-Bl. (1947) in Br.-Bl. et al. 1952. Similar kind of habitats are covered by hygro-mesic meadows of poljes (at Blidinje lake) from the order Trifolio-Hordeetalia Horvatić 1960 and alliance Molinio-Hordeion secalini Horvatić 1934 with following communities: Plantaginetum altissimae Riter-Studnička 1954, Deschampsio-Plantaginetum altissimae Ilijanić 1974 and Scillo litardiereiRanunculetum ${ }^{*}$. Around upland springs we can find some fragments of swampy meadows from the order Deschampsietalia Horvatić (1956) 1958, alliance Deschampsion caespitosae Horvatić 1930 and Deschampsietum caespitosae Horvatić 1930. The most humid types of soil, which are on the way to get transformed into bogs, are inhabited by hygrophylous meadows from the order Molinietalia W. Koch 1926, alliance Molinion coeruleae W. Koch 1926 (communities: Gladiolo-Molinietum coeruleae Horvat 1962, Molinietum coeruleae W. Koch 1926 and Seslerio uliginosae-Caricetum paniceae ${ }^{\star}$ ), then the alliance Calthion palustris Tx. 1937 and community Filipenduletum ulmariae from the alliance Filipendulion (=Filipendulo-Petasition Br.-Bl. 1947). The vegetation along forest roads and on clearings in woods belongs to wider distributed order Plantagini-Prunelletalia Ellmauer \& Mucina 1993 and alliance Plantagini-Prunellion Eliás 1980, while on trampled places vegetation from the alliance Potentillion anserinae R.Tx. 1947 encompassed by the order Potentillo-Polygonetalia R. Tx. 1947 occur.

\section{Vegetation of swamp and water ecosystems}

Even though the whole area of endemic centre of Prenj, Čvrsnica and Čabulja mountains is built of permeable carbonate rocks, occasionally there are certain forms of water-resistant surfaces and soils with developed pedological profile that in most part is moist throughout a year. This vegetation on researched areas is developed along the coastline of Blidinje lake on Dugo polje below Čvrsnica, especially along Boračko lake in foothills of Prenj, along glacial Crljensko lake on Vilinac (Čvrsnica), along smaller flows (Masna Luka on Čvrsnica), and partially along Neretva river and its confluents. Even though this vegetation is developed on small surfaces, it has a great ecological meaning and makes this area very diversified and rich. In such ecological circumstances different types of communities exist, that create a productive component of several ecosystems.

Ecosystems of marshes with reedbeds occur in a form of smaller fragments which develop along standing water and mountain lakes.

It is encompassed by the class Phragmiteto-Magnocaricetea Klika in Klika \& Novak 1941 (Syn.: Phragmitetea Tx. \& Prsg. 1942 p.p.), order Nasturtio-Glycerietalia Pignatti 1953, and communities from the alliance Sparganio-Glycerion Br.-Bl. \& Siss. in Boer. 1942. The reedbed community Scirpo-Phragmitetum australis W. 
Koch 1926 from the alliance Phragmition communis W. Koch 1926, and order Phragmitetalia W. Koch 1926 occurs on alkaline bogs at Boračko lake. Going toward more terrestric soil this community makes ecological continuity with sedge communities Caricetum elatae W. Koch 1926 and Caricetum gracilis R.Tx. 1937 from the alliance Magnocaricion elatae W. Koch 1926. The inshore belt, in which organic biomass achieves a high rate of turnover, comprises fragments of hygrophylous communities from the alliance Oenanthion aquaticae Hejný ex Neuhäusl 1959.

Especially indicative is the presence of community Scheuzherio-Caricetea fuscae (Norh.1936) Tx. 1937 in Masna Luka below Čvrsnica mountain, as well as different communities with reed, sedge and other aquatic plants. This class includes the vegetation of blanket bogs from the order Caricetalia davallianae Br.-Bl. 1949, which characterizes the alliance Caricion davallianae Klika 1934 of boreal distribution. Though covering a smaller area, it is represented here by three communities: Eriophoro-Caricetum paniceae Horvat 1962, Veronico beccabungae-Eriophoretum latifoliae ${ }^{*}$ and Mentho longifolii-Eriophoretum latifoliae ${ }^{*}$. In transitional zone of bogs occur fragments of boreal communities Caricetum fuscae Br.-Bl. 1915 and Eleocharetum ovatae Hayek 1923 from the alliance Caricion fuscae W. Koch $1926 \mathrm{em}$. Klika 1934 (Syn.: Caricion canescentis-fuscae) and order Caricetalia fuscae W. Koch 1926 em. Br.-Bl. 1949.

In this area, the inshore belt of mountain lakes, as well as the estuaries of their affluents, are covered by aquatic vegetation that belongs to the widely spread class Potamogetonetea Klika in Klika \& Novák 1941 (Syn.: Potametea R.Tx. \& Prsg. 1942). The order CalitrichoPotametalia W. Koch 1926 with the alliance Ranunculion fluitantis Neuhäusl 1959 comprises oligodominant communities of clear brooks, which occur mainly around Boračko lake. The aquatic communites of mountain lakes belong to the order Potamogetonetalia W. Koch 1926 (Syn.: Potametalia W. Koch 1926) and are characterized by three ecologically different community types: (i) submerged vegetation from the alliance Magnopotamion (Syn.: Potamion eurosibiricum W. Koch 1926) with Nasturtio-Beruletum angustifoliae submersae RiterStudnička 1972 and Myriophyllo-Nupharetum W. Koch 1926, while in warmer litoral waters communities from the alliance Ceratophyllion demersi Soó 1927 occur. The floating vegetation, which is composed of plants that are not rooted at the bottom, is comprised by nenuphar communities from the alliance Nymphaeion albae Oberdorfer 1957.

The freshwater vegetation in the litoral belt is of patchy character. It is encompassed by the class IsöetoNanojuncetea Br.-Bl. \& Tx. 1943 and its order Isoetetalia
Br.-Bl. 1931, which is alliance Nanocyperion flavescentis W. Koch 1926 and Fimbrystilion dichotomae Horvatić 1954.

In so-called "dead", standing water, of effluents that surround the Boračko lake, developed communities of floating unrooted vascular plants from the cosmopolite class Lemnetea W. Koch \& Tx.1954, order Lemnetalia W. Koch \& Tx.1954 and alliance Lemnion W. Koch \& Tx.1954. Similar kind of habitats are inhabited by communities of cryptogammes with green algae from the class Charetea fragilis Fukarek 1961 ex Krausch 1964, order Charetalia hispidae Sauer ex Krausch 1964 and alliances Charion fragilis Krausch 1964 em. W. Krause 1969 and Charion vulgaris (Krause ex Krause \& Lang 1977) Krause 1981. The vegetation that develops around mountain springs and smaller streams is of glacial character. It belongs to the class Montio-Cardaminetea Br.-Bl. \& Tx. ex Klika 1948, order Motio-Cardaminetalia Pawlowski in Pawlowski, Sokolowski \& Wallisch 1928 and alliances Cardamino-Montion Br.-Bl. 1926 em. Zechmeister 1993, while on tuff the alliance Cratoneurion commutati W. Koch 1928 occurs.

Vegetation of mesophyllous tall herb communities (Mulgedio-Aconitetea Hadač \& Klika in Klika 1948)

Same as communities of class Trifolio-Geranietea Müller 1962, communities of tall herbs are developed in the ecotones areas. However, this vegetation develops in the zone of mesophyllous forests and bushes. Soils are mildly nitrified kalkokambisol or deeper kalkomelanosol in the zone of mesophyllous forests of beech, spruce and fir, as well as spruce and white-barked pine. This vegetation was previously developed at the bottoms of sinkholes where snow remains longer. This vegetation type belongs to the order Adenostyletalia Br.-Bl. 1931 and includes several plant communites from the Alpine-dinaric alliances: Adenostylion alliariae Br.-Bl. 1925, Petasition dörfleri Lakušić 1968 and Knautio-Veratrion albae*.

Vegetation of tall herb communities on nitrified soil that develops next to mountain cottages and sheepfolds forms a special dinaric community Senecio rupestrisChenopodietum boni-henrici ${ }^{*}$, from the alliance Rumicion alpini Klika \& Hadač 1944, order Rumicetalia alpini Mucina in Karner et Mucina 1993.

In a development sense this vegetation is ecological connection between mesophyllous woods and mesophyllous grasslands. A special value in this type of vegetation are communities of endemic alliances Petasition dörfleri Lakušić 1968 and Veratrion that connect tall herb communities with sub-alpine meadows of the endemic alliance Pancicion Lakušić 1966. 
Vegetation of ecosystems of mesophyllous broadleaved-deciduous forests and thickets (Querco-Fagetea Br.-Bl. \& Vlieger in Vlieger 1937)

Deciduous forests and thickets, on the investigated area are spread on wide belt - from lowest parts (around $250 \mathrm{~m}$ above see) all the way up to sub-alpine belt $(1,600$ $\mathrm{m}$ and $1,800 \mathrm{~m}$ ) where they end at sub-alpine low forests of beech (Fagetum "subalpinum" Horvat 1949). Depending on hydro-thermic regime they are differentiated into thermic and semi-humid ones. Terrains where they develop are rendzine and kalkomelanosol, as well as kalkokambisol, on flattened terrain, rarely luvisol. Within these ecosystems, a special place is given to different beech forests that are developed in hill, hill-Mediterranean, upland and sub-Alpine belts. Content of this vegetation includes 20 associations, 8 alliances and 3 orders. The deciduous mesophyllous forests in dependence of hydric regime and floristic composition, as well as of soil depth, are differentiated in three orders: (i) Betulo pendulo-Populetalia tremulae Rivas-Martínez \& Costa (progradation stages with trembling poplar and hazel from the alliance Corylo-Populion tremulae Br.-Bl. 1961 and community Capreeto- Populetum tremulae Glišić (1950)1975; (ii) Fagetalia sylvaticae Pawlowski in Pawlowski, Sokolowski \& Walisch 1928 (beech woods) and (iii) Rhamnetalia fallacis Fukarek 1969 (scrubs of Rhamnus L.on limestone blocks in the upland belt with the community Cynancho-Rhamnetum Fukarek 1969 from the alliance Lonicero-Rhamnion Fukarek 1969.

In the lowest part of the area (upper and mid flow of Neretva river), the order Fagetalia Pawlowski in Pawlowski, Sokolowski \& Walisch 1928 is represented by communities of hornbeam and sessile oak QuercoCarpinetum betuli (Horvat 1938) em. Blečić 1958 from the alliance Carpinion betuli Oberdorfer 1953, while in warmer habitats it alternates with the illyrian oak-hornbeam woods from the alliance Erythronio-Carpinion (Horvat 1958) Marinček in Wallnöfer et al. 1993. Above this vegetation belt develops the belt of beech woods which is differentiated into four alliances: (i) illyrian beech forest Aremonio-Fagion Török et al. 1989 (Syn.: Fagion illyricum p.p.) in cold habitats, often on north facing sloes and deep karstic soil; (ii) moesian beech forests Fagion moesiacae Blečić \& Lakušić 1970, on extremely karstic terrain and shallow soil of A-C profile, and on south facing slopes; (iii) xeric beech forests on dolomite Cephalanthero-Fagion Tüxen 1955 and (iv) forests of beech and hope hornbeam Ostryo-Fagenion Borhidi ex Soó 1964, on limestone blocks and steep slopes with very shallow soil types.

The illyrian beech woods are highly diverse. In the investigated area, they are differentiated into several communities: Fagetum "montanum illyricum" Fukarek \&
Stefanović 1958, Abieti-Fagetum "illyricum" Horvat 1958, Aceri-Fagetum "subalpinum" Fukarek \& Stefanović 1958, Seslerio -Fagetum Moor 1952, Aceri obtusati-Fagetum Fabijanić, Fukarek \& Stefanović ex Fukarek, Stefanović \& Fabijanić 1967 and Aceri-Tilietum "mixtum" Stefanović 1979 (polydominant community in the canyon of Neretva river and its larger affluents), and typical karst community from Čvrsnica mountain Fagetum "mediterraneo-montanum" Redžić et al. 1984 (Redžić \& Barudanović 2010).

The moesian beech forests Fagion moesiacae Blečić \& Lakušić 1970 comprise the following communities: Seslerio autumnalis-Fagetum moesiacae, Fagetum moesiacae "montanum" Blečić \& Lakušić 1970, Aceri obtusatiFagetum moesiacae Fabijanić, Fukarek \& Stefanović 1963, Abieti-Fagetum moesiacae Horvat, Glavač \& Ellenberg 1974, Aceri-Fagetum moesiacae Jovanović 1957, Pino heldreichi-Fagetum moesiacae "mediterraneo-montanum", Pino heldreichii-Fagetum moesiacae "subalpinum" and Rhamno fallacis-Fagetum moesiacae.

In the upland belt the very representative communities are of beech and fir Abieti-Fagetum, and communities of Rhamnus L. from the order Rhamnetalia fallacis Fukarek 1969, developed on limestone blocks and shallow humus layer. A special value is given to thermophyllous communities of beech and hope hornbeam OstryoFagenion Borhidi ex Soó 1964, and forests of beech and white-barked pine Fago-Pinetum heldreichii s.lat.

Fragments of acidophilus communities of class Quercetea robori-petraeae Br.-Bl. \& R.Tx. 1943, order Quercetalia robori-petraeae Tx. 1931 and group Castaneo-Quercion petraeae Soó $1962 \mathrm{em}$. 1971, are found here, within which fragments of chestnut and sessile oak on acid substrates in Jablanica surrounding were determined.

Vegetation of ecosystems of broadleaved-deciduous thermophyllous forests and scrubs (Quercetea pubescentis (Oberdorfer 1948) Doing Kraft 1955; Syn.: Querco-Fagetea p.p.)

In warmer habitats, on shallow soils - rendzine and organic-mineral humus, colluviums soils in bases of mountains, as well as on kalkokambisol on flatter terrains, form lowest areas to upland belt. There, forests and scrubs of hornbeam, pubescent oak, Turkey oak, Italian oak and hope hornbeam are developed. In the content of class Quercetea pubescentis (Oberdorfer 1948) Doing Kraft 1955 in this area 17 communities of association levels, 7 of alliance level and three of order level are determined.

Even though they form a wide belt, the optimum is in the valley of Neretva river and its confluents, where it gives a specific phyto-geographic mark to this area. In ecological - typological sense, we differentiate low forests 
and scrubs of white hornbeam Carpinion orientalis Blečić \& Lakušić 1966, black hornbeam and autumn blue moor grass Seslerio-Ostryetum, within which are endemic and endemic - relict communities. Other types are forests of Italian oak Quercion confertae Horvat 1954 and pubescent oak Ostryo-Quercion pubescentis, as well as forests of Turkey oak Quercion cerris Lakušić 1976. Deciduous thermophyllous forests and thickets are much degraded today. Despite this, they contain a whole floristic wealth and significant number of endemic - relict species. These are special kind of habitats for diverse animal species.

In respect to their ecology and physiognomy thermophyllous woods and thickets are differentiated in three orders: (i) Fraxino orni-Cotinetalia Jakucs 1961 (thicket communities with Christ's-Thorn Paliuretum aculeate Auct) and Pistacio lentisci-Carpinetum orientalis $^{*}$ (transitional thicket communities between mediterranean and supra-Mediterranean belt) from the alliance Paliuro-Carpinion orientalis*.

There are well-preserved woods with pubescent, Turkey and Italian oak around Jablanica, upper flow of Neretva river, and slopes of Čabulja mountain. They are comprised by the order Quercetalia pubescentis Br.-Bl. (1931) 1932 and several alliances. The communities of Italian oak with hope hornbeam are encompasssed by the alliance Quercion pubescentis-petraeae Br.-Bl. 1931 and communities: Carpino orientalis-Quercetum pubescentis, Ostryo carpinifoliae-Quercetum pubescentis and Querco-Ostryetum carpinifoliae Horvat 1938.

Woods of Italian oak in Herzegovina are of relict character. They belong to the alliance Quercion confertae Horvat 1954 and most unique association Quercetum farnetto "hercegovinum" Fukarek (1963) 1966.

On acid soil, which is hard to be found here (the valley of Doljanka river), occur fragments of acidophyllous oak woods Quercetum petraeae "montanum" Stef. (1961) 1964 and the alliance Quercion petraeae Zalyomi \& Jakucs ex Jakucs 1960. In similar kind of habitats develop also fragmented woods with Turkey oak, from the alliance Quercion cerris Lakušić 1976.

The most frequently occuring are low forests, thickets and shrubs with oriental hornbeam and hope hornbeam from the order Ostryo-Carpinetalia orientalis Lakušić, Pavlović \& Redžić 1982. Shrubs with oriental hornbeam from the alliance Carpinion orientalis Blečić \& Lakušić 1966 achieve the extremely high diversity level. They are differentiated into following communities: Seslerio autumnalis-Carpinetum orientalis*, Cruciato glabrae-Carpinetum orientalis, Aceri-Carpinetum orientalis Blečić \& Lakušić 1967, Melampyro trichocalycinaeCarpinetum orientalis, Petterio-Carpinetum orientalis, Rusco aculeati-Carpinetum orientalis Blečić \& Lakušić 1967 and Punico-Carpinetum orientalis. The relict wood with hope hornbeam and autumn moor grass from the alliance Seslerio-Ostryon Lakušić, Pavlović \& Redžić 1982 comprises two communities, which are: Seslerio autumnalis-Ostryetum carpinifoliae Horvat \& Horvatić 1950 and Fraxino orni-Ostryetum carpinifoliae.

\section{Vegetation in ecosystems of hygrophyllous forests} and shrubs

Along the water flows of researched area and along the coastline of Blidinje and Boračko lakes, as well as on rare water resistant biotopes, in a form of smaller fragments, isolated area, and different forms of hygrophyllous communities are developed. The vegetation of hygrophyllous shrubs with purple willow, on swampy kind of soil along watercourses, of the class Salicetea purpureae Moor 1958, order Salicetalia purpureae Moor 1958, comprises the shrub formations with purple willow Salicion purpureae Lakušić 1975 and Salicion triandrae Th. Müller \& Görs 1958. In some places fragments of white willow Salicion albae R. Tx. 1955 occur. The inshore belt of rivers and streams, which frequently dries out, comprises fragments of communities from the alliance AlnoQuercion roboris Horvat 1938, as well as of Populion albae Br.-Bl. ex Tchou 1948 and Alnion glutinosae (Malc. 1929) Meier Dr. 1936 alliances.

Even though this vegetation is spread on small a territory at the area of endemic development centre, it has great ecological meaning in total image of rich biological diversity.

Ecosystems of mesophyllous and thermophyllous shrubs (Rhamno-Prunetea Rivas Goday \& Borja Carbonell 1961)

At many places, forest and thicket are degraded and today converted into lower forms of organization of ecosystems. Most dominant type of this vegetation are communities of shrubs that are very often a long lasting stage in development of more complex forms of vegetation. These are also specific ecotones that are characterized with extraordinary floristic richness. Shrub communities of mesophyllous and mesophyllic-thermophyllous character belongs to the order Prunetalia spinosae R. Tx. 1952 and alliances: (i) Berberdion vulgaris Br.-Bl. 1950 with the community Evonymo-Rhamnetum catharticae $^{\star}$; (ii) Crataego-Corylion Fukarek 1969, shrubs of hazel with following associations: Helleboro-Coryletum avellanae Redžić 1990, Crataego-Coryletum avellanae Fukarek 1969 and (iii) Prunion spinosae Soó 1951 with the community Crataego-Prunetum spinosae Beus 1971. The greatest physiognomic meaning have the hazel communities, alliance Crataego-Corylion Fukarek 1969, barberry Berberidion and blackthorn Prunion spinosae Soó 1951. 
Vegetation in ecosystems of heaths (LoiseleurioVaccinietea Eggler ex Schubert 1960)

On the investigated area heaths are developed on carbonate shallow soil of type of rendzine and humus in the sub-alpine and upland belt. These are communities of low evergreen shrubs, in which prevail species from genus Juniperus L. Heaths are here encompassed by the order Rhododendro-Vaccinietalia Br.-Bl. in Br.-Bl. \& Jenny 1926 and the alliance Juniperion nanae Br.-Bl. et al. 1939 in sub-alpine belt, while in upland and hilly belt the alliance Juniperion communis occurs.

Distinguished ecological meaning is given to communities of mountain peaks from the alliance Juniperion nanae Br.-Bl. et al. 1939, in upland belt, in the zone of white-barked pine Pinetum heldreichii "mediterraneomontanum" Blečić \& Lakušić 1969 and the community Juniperetum communis-intermediae Stefanović 1974.

Vegetation in ecosystems of relict pine forests (Erico-Pinetea Horvat 1959)

On the investigated area relict pine forests have a great meaning. They are so different in both ecological and in floristic sense compared to other congenital types of vegetation that they belong to a separate phytogeographical province - relict pine forests. They are very common on dolomites and dolomitic limestones. Therefore, they have a role of refuge of Tertiary flora and vegetation. Syntaxonomical, this vegetation is differentiated into three vegetation orders: (i) Erico-Pinetalia (Oberdorfer 1949) em. Horvat 1959 (relict black pine forests on dolomite) with two alliances: Fraxino orni-Ericion Horvat 1958 and Fraxino orni-Pinion nigrae Zupančič 2007 (ii) Pinetalia heldeichii-nigrae Lakušić 1972 (forests of white-barked pine and illyrian black pine) in the upland and sub-alpine of Prenj, Čvrsnica and Čabulja mountains and (iii) order Rhododendro hirsuti-Ericetalia carneae Grabherr, Greimler \& Mucina 1993 (shrubs of mountain pine with heath on dolomite in both alpine and upland belt) with the relict alliance Pino mugi-Ericion and endemo-relict community Gentiano dinaricaeEricetum carneae identified on Prenj mountain.

Vegetation order Pinetalia heldreichii-nigrae Lakušić 1972 is differentiated into the alliance Pinion nigrae Lakušić 1972 (forests of illyrian black pine in the canyon of Neretva river and its affluents) with relict black pine forests combined with hope hornbeam OstryoPinetum nigrae Trinajstić 1999 and forests of black pine with "omorikoides" spruce Pino nigrae-Piceetum abietis "omorikoides" Lakušić \& Redžić 1989 in the sub-alpine belt of Čvrsnica mountain.

Forests of tertiary relict white-barked pine from the alliance Pinion heldreichii Horvat 1950 are differentiated into three associations: Pinetum heldreichii "mediteran- neo-montanum" Blečić \& Lakušić 1969, Junipero-Pinetum heldreichii (Blečić 1960) Fukarek 1970 and Fago-Pinetum heldrechii Janković (1972) 1975.

Beside the community of Illyrian black pine Pinion nigrae Lakušić 1972, special feature to this area is given by forests of endemic Balkan white-barked pine Pinion heldreichii Horvat 1950 that is further differentiated to several endemic - relict associations. Along with these associations, a special rareness are fragments of community of spring heath in the sub-alpine belt Pino mugiEricion carneae, that is on Prenj mountain represented by endemic association of Gentiano dinaricae-Ericetum carneae*.

Vegetation in ecosystems of mountain pine (Roso pendulinae-Pinetea mugo Theurillat 1995 in Theurillat et al. 1995)

Upper timberline in the investigated area is represented by mountain pine Pinetum mugi Hadač 1956. Due to strong mountain winds and deep and long-lasting snow, mountain pine has flattened physiognomy. Soils are organic kalkomelanosol and rendzine. Syntaxonomical, vegetation of mountain pine is differentiated into order Junipero-Pinetalia mugi. The alliance Pinion mugo Pawlowski in Pawlowski, Sokolowski \& Wallisch 1928 comprises communities of mountain pine from the sub-alliance Violo biflorae-Pinenion mugo Redžić 2000 with association Pinetum mugi "dolomiticum", Geranio silvaticae-Pinetum mugi* and Pinetum mugi "calcicolum" Lakušić et al. 1973. The alliance Erico carneae-Pinion mugi Leibundgut 1948 em. Redžić 2000 includes the community Erico carneae-Pinetum mugo Redžić 2000 on warmer dolomite type of soil in the sub-alpine belt, which on southern and western slopes of Čvrsnica mountain. descends to $1,300 \mathrm{~m}$ above sea level.

Vegetation in ecosystems of dark coniferous forests (Vaccinio-Piceetea Br.-Bl. in Br.-Bl. et al. 1939)

At north and northwestern slopes of Čvrsnica, communities of dark conifer forests are developed in fragments. They are especially representative below the peaks Pločno and Vilinac, toward Masna Luka. They are developed on carbonate surface, on soils of A-C profile - humus and rendzine. It is important to emphasize that on these biotopes there is a mix of thermofile populations of spruce Picea abies (L.) H.Karst and the coldest populations of white barked pine Pinus heldreichii H. Christ. Syntaxonomically, this vegetation is differentiated on two orders: (i) Vaccinio-Piceetalia Br.-Bl. 1939, alliance Vaccinio-Piceion Br.-Bl. 1938 with communities: Pino heldreichii-Piceetum abietis* and Abieti-Piceetum abietis pinetosum heldreichii* and (ii) Calamagrosti-Abietetalia Fukarek 1969 (forests of dinaric fir on limestone blocks), with the 
alliance Calamagrosti-Abietion Horvat 1963 and the community Calamgrosti-Abietetum albae Horvat 1950.

At coldest biotopes there are communities of fir and spruce Abieti-Piceetum abietis bosniacum Lakušić et al. 1979, and at limestone blocks there are communities of Calamgrosti-Abietetum albae Horvat 1950, especially presented on northern slopes of Prenj.

\section{Vegetation of arable, rural and abandoned eco-} systems

Anthropogenic impact in some areas is so distinguished that it lead to conversion not only primarily to secondary, but also secondary to less organized communities. By their origin, they are tertiary. Those are communities on cultivated surfaces, abandoned biotopes, along houses, roads, trampled places. Soils, without consideration of their original nature and type, are nitrified and troubled. Depending on intensity and nature of action of anthropogenic factor in the past, tertiary vegetation is differentiated to following communities that participate in building of several ecosystems: (i) ecosystems of arable and abandoned places from the class Stellarietea mediae R. Tx., Lohmeyer \& Preising in R. Tx. ex von Rochow 1951, order Atriplici-Chenopodietalia albi R. Tx. (1937) Nordhagen 1940 and alliances Panico-Setarion Siss. in Westhoff et al. 1946 and Polygono-Chenopodion polyspermi W. Koch \& R. Tx. 1937; order Chenopodietalia Br.-Bl.1931 em.1936 with communities of Chenopodion muralis Br.-Bl. (1931) 1936 and Hordeion Br.-Bl. (1931) 1947 alliances, on warmer nitrified soil: (ii) ecosystems of humid and nitrophyllous vegetation from the class Bidentetea tripartiti Tx. Lohmeyer \& Preising 1950, order Bidentetalia Br.-Bl. \& Tx. 1943 and Menthion pulegii Lakušić 1973 community; (iii) ecosystems of trampled and poorly aerated soils of the class Plantaginetea majoris Tüxen \& Preising in Tüxen 1950, order Plantaginetalia majoris R. Tx. 1950 and alliances Polygonion avicularis Br.-Bl. 1931 ex Aich. 1933 and Agropyro-Rumicion crispi Nordhagen 1940 (iv) ecosystems of abandoned nitrified places from the class Chenopodietea Br.-Bl. 1951, order Onopordetalia Br.-Bl. \& R. Tx. 1943 ex Klika \& Hadač 1944 and the alliance Arction lappae Tx. 1937 em. Siss. 1946 and (v) ecosystems of dried nitrified soil from the class Artemisietea vulgaris Lohmeyer et al. ex von Rochow 1951 encompassed by the order Artemisietalia Lohmeyer ap. Tx. 1947 and alliances Artemision absinthii Lakušić et al. 1975 and the endemic alliance Cirsion candelabri* ${ }^{*}$.

Communities of tertiary vegetation unlike previous types of primarily and secondary vegetation mostly do not contain endemic species. Exceptions are communities form the alliance Cirsion candelabri ${ }^{\star}$ that are present along roads on Prenj and Čvrsnica mountains. Besides, in optimal measure, these communities and their floris- tic structure are beneficial to richness of biological diversity and diversity of biotope.

\section{GIS INTERPRETATION OF MAIN TYPES OF KARST VEGETATION}

Distribution of basic types of communities is given in GIS interpretation in original proportion 1: 25000 (Figs. 4 \& 5) for the whole area of endemic development centre in complex of mountains of Prenj, Čvrsnica and Čabulja.

Due to variable mosaic distribution caused by distinguishing relied as well as other factors of non-biotic nature, cartography and in this proportion, it was impossible to present communities at level of association. In order to do it this overview was conducted on level of groups, order and sometimes class, or type. However, the offered GIS cartographic interpretation could definitely be used for the following purpose: to consider and assess real conditions of biological and geological - morphological and hydrological diversity of this complex area.

Total area of endemic centre of Prenj, Cvrsnica and Čabulja mountains covered by this research was about 105,000 ha. In the area of Prenj mountain coverage is about 51,754.38 ha, while in the complex of Čvrsnica and Čabulja mountains it is $51,752.72$ ha. In both areas at higher altitudes (that are at the same time very valuable from aspect of biological and geo-morphological diversity) mountain pastures are dominating, rock creeps, glaciers and crak in the rocks and sub-mountain forests of white barked pine Pinetum heldreichii s.lat, sub-mountain forests of beech and maple Aceri-Fagetum "subalpinum" are present. In lower parts, on south expositions, on shallow soils deciduous woods and thicket of Moesian beech, black hornbeam are present, while in the valleys, especially in canyon of river Neretva, shrubbery and coppice with white hornbeam Carpinetum orientalis s.lat are present. Besides what has already been mentioned, the cartographic presentation provides an overview over distribution of similar types of vegetation that represent the real condition of bio-cenological, as well as floristic biodiversity at the territory of the endemic centre.

The situation on the mountain of Prenj is mostly the same as at the territory of mountains of Čvrsnica and Čabulja research area. On this mountain complex different forms of deciduous forests and their pro-gradation - degradation stages dominate (Figs. 4 \& 5).

In the spectre of vegetation, the biggest proportion is of deciduous forests of beech and its different development stages (especially at the territory of Čabulja), then thermofile woods of oak and their degradation stages - coppice and shrubbery of white hornbeam and black hornbeam, as well as vegetation of thermofile meadows and bullhead (Figs. 4 \& 5). 
Tab. 6: Comparative overview of vegetation diversity of the endemic centre of Prenj, Čvrsnica and Čabulja mountains with same parameters used for different geographical areas.

\begin{tabular}{l|l|l|l|l|l}
\hline Geographic region & Class & Order & Alliance & Association & Source \\
\hline Europe & 80 & 233 & 928 & $?$ & Rodwell et al. 2002 \\
\hline Bosnia andHerzegovina & 33 & 60 & 113 & 314 & Lakušić et al. 1978 \\
\hline Montenegro & 37 & 53 & 97 & 267 & Blečić \& Lakušić 1976 \\
\hline Croatia & 42 & 61 & 120 & 408 & Trinajstić 2008 \\
\hline Vranica mountain (Bosnia and Herzegovina) & 27 & 44 & 73 & 165 & Redžić 2007 \\
\hline Endemic centre Prenj-Čvrsnica-Čabulja & 34 & 63 & 116 & 236 & this paper (Redžić et al.) \\
\hline
\end{tabular}

Tab. 7: Proportions of some syntaxonomical categories of the endemic centre of Prenj, Čvrsnica and Čabulja mountains in the vegetation of selected geographical area.

\begin{tabular}{l|l|l|l|l}
\hline Region & Class & Order & Alliance & Association \\
\hline $\begin{array}{l}\text { Endemic centre } \\
\text { Prenj-Čvrsnica-Čabulja }\end{array}$ & 34 & 63 & 116 & 236 \\
\hline Proportion in Europe (\%) & 42.5 & 27 & 12.5 & - \\
\hline Proportion in Bosnia-Herzegovina (\%) & $>100$ & $>100$ & $>100$ & 75 \\
\hline Proportion in Montenegro (\%) & 92 & $>100$ & $>100$ & 88 \\
\hline Proportion in Croatia (\%) & 81 & $>100$ & 97 & 58 \\
\hline
\end{tabular}

Prenj-Čvrsnica-Čabulja. As much as $92 \%$ of classes and $88 \%$ of association of Montenegro were numerically contained in the vegetation of this endemic centre. This includes especially the mountains Maglić, Volujak, Durmitor, Bjelasica, Sinjajevina,

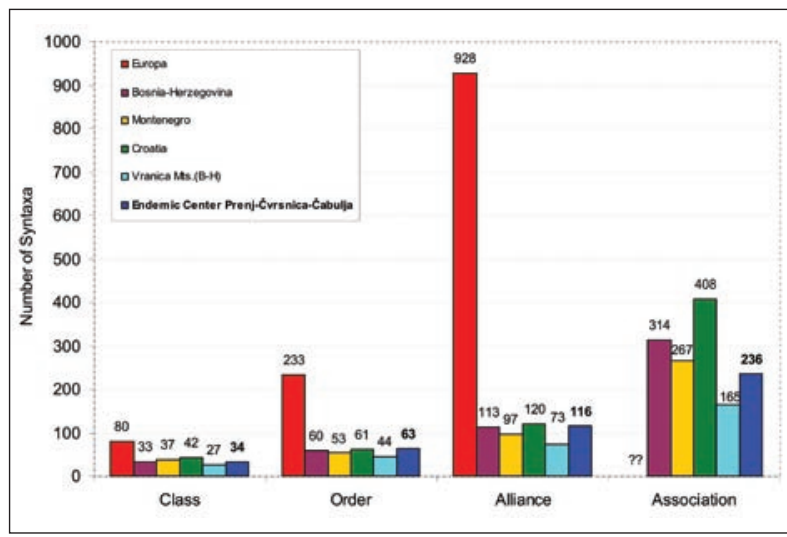

Fig. 6: Comparative overview of syntaxonomical diversity of Bosnia and Herzegovina with same parameters used in region and Europe.

\section{HIGH LEVEL OF VEGETATION RICHNESS}

Considering this extremely important parameter, as one of the best indicators for specific ecological diversity, the area of endemic centre of Prenj, Čvrsnica and Čabulja is considered to be one of the richest and most unique ones not only in Bosnia and Herzegovina and Dinaric Alps, but also in the entire Mediterranean area and Europe (Tab. 6). Thus, this area represents the biodiversity "hot spot" in SE Europe, and perhaps even wider (Redžić 2008a, 2008c).

This claim is illustrated in 314 associations, 113 alliances, 60 orders and 33 classes which were described so far on the territory of Bosnia and Herzegovina (Lakušić et al. 1978) (Fig. 6). Compared with the vegetation diversity of Montenegro Blečić \& Lakušić (1976) found high proportion of syntaxa in endemic development centre

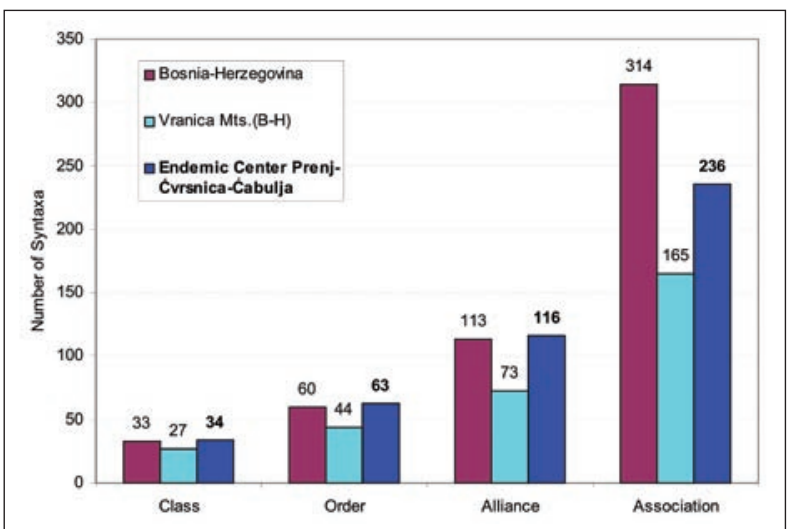

Fig. 7: Comparative overview of syntaxosonomical diversity of endemic centre of Prenj, Čvrsnica and Čabulja mountains at Bosnia and Herzegovina's level.

Prokletije, Komovi, Haila, Lovćen and Rumija (Lakušić 1970; Blečić \& Lakušić 1976; Lakušić \& Redžić 1989).

Comparison of vegetation diversity is made with Croatian vegetation (Trinajstić 2008). The most recent survey of vegetation in neighbouring Croatia showed a high level of syntaxonomical diversity (Tab. 6). Croatian vegetation belongs to 42 classes, 61 orders, 120 alliances and 408 associations. There is a high proportion of associations of endemic centre in the total number of plant communities of Croatia (58\%). However, endemic development centre Prenj-Čvrsnica-Čabulja is richer in alpine and sub-alpine communities of the vegetation class Elyno-Seslerietea, Salicetea herbaceae and Asplenietea trichomanis (Tab. 6 \& Fig. 6). 
If compared with the European ecological diversity (Ellenberg 1986; Rodwell et al. 2002), the territory of this endemic centre shows extremely high level of diversity (Tab. 6). Out of 928 vegetation units, as it was recorded in Europe by now, $13 \%$ were recognized at this territory. Vegetation units at level of order, which are to be found here, participate with $27 \%$ in the vegetation diversity of Europe, while share of classes amounts $43 \%$ in the European vegetation (Tab. 7).

In addition, the ecological diversity of this area exceeds extremely high diversity like the one that was noted on silicate - carbonate massif of Vranica mountain in central Bosnia (Lakušić et al. 1979; Redžić 2007c, 2007d).
It is important to stress that diversity at some levels, for example at level of higher syntaxa (Fig. 7), is higher than in Bosnia and Herzegovina.

Similar relation is in view of proportions and number of vegetation orders, as well as classes as highest forms of vegetation integrity. These data unquestionably indicate that this endemic centre is truly unique, biologically rich and that it makes specific "hot vegetation spot" in both Mediterranean and whole Europe. On the other side, these data indicate still rather weak research of biological diversity, and specially syntaxonomy of plant cover in karst at the territory of Bosnia and Herzegovina.

\section{CONCLUSIONS}

The mountain complex Prenj, Čvrsnica and Čabulja in Herzegovina is considered to be one of the largest karst regions in Dinaric Alps and even wider. Besides, this mountain complex encompasses some of the highest peaks of central and litoral Dinaric Alps.

Specific forms of geogenesis, orogenesis and genesis of climate that took place in the long history of the Earth, have led to extremely high diversity of karst phenomena, such as sinking rivers, karren, sinkholes, and caves, which are today most unique habitat types with rich wilderness.

In the sub-alpine and alpine belt cirques and snowbeds occur; as a remnant of glaciation that happened in past and after going through karstic hydrogenesis resulted in development of mountain (glacial) lakes. These lakes are today most unique ecosystems with a spectre of both plant and animal species of glacial-relict character.

This unique forms of geogenesis, orogenesis, hydrogenesis and genesis of climate have caused specific directions of pedogenesis, which led to occurence of diverse developmental series of carbonate soils - various forms of lithosol on bare rocks, regosol in crevices of carbonate rocks, calcomelanosol and rendzine, while on flat ground deeper soil types such as calcocambisol, modified terra rossa and calcoluvisol occur in the lowest areas. By means of powerfull currents at mountain foot, recent alluvial depositions and colluvium evolve daily.

The unique pattern of evolution of abiotic ecosystem components was a fundamental determinant for specific forms of karstogenesis in this area, which corresponds directly with unique patterns of genesis of flora and syngenesis, respectively development of flora and vegetation. These unique and diverse forms of karstogenesis provide the answer to high floristic richness, as well as to extremely high level of endemism and relictness. Because of that, this area has got every right to be designated as the endemic development centre, and after this research and modern evaluation process even as a biodiversity hotspot of great importance not only for the Mediterranean, but on global scale.

\section{AKNOWLEDGEMENTS}

This paper was co-financed by means from the scientific-investigation project: "Procjena ugroženosti i obrasci održive zaštite genofonda endema u razvojnom centru Prenj-Črrsnica-Čabulja" ("Assessment of threats and patterns for the sustainable protection of endemic gen pool in the development centre Prenj-Čvrsnica-Čabulja"), Project Number: 03-39-5980-67-2/08, co-financed by the Federal Ministry of Education and Science of Federation of Bosnia and Herzegovina.
Major contribution to the project's realization was provided by consultants: academician Ljubomir Berberović, academician Taib Šarić and academician Mithat Usčuplić, Center for Carstology at the Academy of Science and Arts of Bosnia and Herzegovina.

Field work in technical respect was realized by the support of technical assistant Sedik Velić. 


\section{REFFERENCES}

Adamović, L., 1907: Pflanzengeographische Stellung und Gliederung der Balkanhalbinsel. Aus der KaiserlichKoniglichen hof - und Staatsdruckerei.- KaiserlichKönigliche Hof-und Staatsdruckerei, pp. $91+3$ Pflanzengeographishen Karten, Wien.

Ashdown, M. \& J. Schaller, 1990: Geographic information systems and their apllication in MAB-projects, ecosystem research and environmental monitoring.- MabMitteilungen 34, German National Committee for the UNESCO, Man and the Biosphere (MAB) Programme, pp. 250, Bonn.

Barudanović, S. \& S. Redžić, 2006: Some aspect of ecological differentiation of thermophillous beech forests on Dinaric Alps.- Glasnik Zemaljskog muzeja Bosne i Hercegovine, 32, 157-166.

Beck-Mannagetta, G., 1901: Die Vegetationsverhältnisse der Illyrischen Länder, begreifend Süd-Kroatien, die Anarnero-Inseln, Dalmatien, Bosnien und Herzegowina, Montenegro, Nordalbanien, den Somdzak Novsborzow und Serbien.- Teil IV, Die Vegetation der Erde. Engelmann, pp. 534, Leipzig.

Beck-Mannagetta, G., Malý, K., Bjelčić, Ž \& P. Fukarek, 1983: Flora Bosnae et Hercegovinae. IV Sympetalae, Pars 4.- Zemaljski muzej BiH, Posebna izdanja, pp.188, Sarajevo.

Bjelčić, Ž., 1987: Endemi u biljnom svijetu Bosne i Hercegovine i problem zaštite.- ANUBiH, Posebna izdanja LXXXII, knjiga 14, 95-102.

Bjelčić, Ž. \& Č. Šilić, 1971: Karakteristične cvjetnice za hercegovački endemni centar - planine Prenj, Čvrsnica i Čabulja.- Glasnik Zemaljskog muzeja Bosne i Hercegovine, 10, 39-57.

Bjelčić, Ž. \& Č. Šilić, 1979: Minuartio handelii-Caricetum ass. nov. - nova zajednica na planini Čvrsnici u Hercegovini.- Glasnik Zemaljskog muzeja Bosne i Hercegovine, 18, 51-56.

Blečić, V. \& R. Lakušić, 1976: Prodromus biljnih zajednica Crne Gore.- Glasnik Republ. zvoda zašt. prirode - Prirodnjačkog muzeja, 9, 57-98.

Bognar, A., 1987: Reljef i geomorfološke osobine Jugoslavije.- In: Bertić, I. (ed.) Veliki geografski atlas Jugoslavije, Sveučilišna naklada Liber, pp. 272, Zagreb.

Bonacci, O., 1987: Karst Hydrology.- Springer Verlag, pp.184., Berlin, Heidelberg.

Božičević, S., 1992: Fenomen krš.- Školska knjiga, pp.103, Zagreb.

Brancelj, A., 2006: The epikarst habitat in Slovenia and description of a new species.- Journal of Natural History, 40, 403-411.
Braun-Blanquet, J., 1964: Pflanzensoziologie.- Springer Verlag, pp. 885, Wien.

Bušatlija, I., 1974: Morfostrukturne i morfoskulpturne karakteristike reljefa Bosne i Hercegovine.- In: Bjelovitić, M. (ed.) Proceedings of the IX Congress of Yugoslav Geographers, 25 ${ }^{\text {th }}-30^{\text {th }}$ September 1972. Geografsko društvo Bosne i Hercegovine, 133-135, Sarajevo.

Culver, D.C. \& B. Sket, 2002: Biological monitoring in caves.- Acta carsologica, 31, 55-64.

Cvijić, J., 1893: Das Karstphänomen.- Penck's Georg. Abhandlungen, V, 3, pp. 114, Wien.

Cvijić, J., 1989: Geografija krasa.- Sabrana dela Jovana Cvijića, Knjiga 7, Srpska akademija nauka i umetnosti, pp. 279, Beograd.

Čarni, A., Košir, P., Karadžić, B., Matevski, V., Redžić, S. \& Ž. Škvorc, 2009: Thermophilous deciduous forests in Southearsten Europe.- Plant Bioystems, 143, $1,1-13$.

Čičić, S. \& J. Pamić, 1979: Geologija Bosne i Hercegovine. Knjiga I: Paleozojske periode.- Geoinženjering, pp. 103, Sarajevo.

Čičić, S., Mojićević, M. \& J. Papeš, 1984: Geologija Bosne i Hercegovine. Knjiga II: Mezozojske periode.Geoinženjering, pp. 314, Sarajevo.

Ellenberg, H., 1986: Vegetation Mitteleuropas mit den Alpen.- 4. Aufl., Ulmer, pp. 989, Stuttgart.

Fairbridge, R.W. (ed.), 1968: The Encyclopedia of Geomorphology.- Reinhold Book Co., pp. 1296, New York.

Florea, L.J. \& H.L.Vacher, 2007: Eogenetic karst hydrology: Insights from the 2004 hurricanes, peninsular Florida.- Ground Water, 45, 439-446.

Frančišković-Bilinski, S., Barišić, D., Vertačnik, A., Bilinski, H. \& E. Prohić, 2004: Characterization of tufa from the Dinaric Karst of Croatia: mineralogy, geochemistry and discussion of climate conditions.Facies, 50, 183-193.

Fukarek, P., 1949: Podaci o geografskom širenju munike (Pinus heldreichii Christ).- Godišnjak Biološkog instituta, 1, 21-41.

Fukarek, P., 1965: Rasprostranjenost i ekološke karakteristike krčagovine (Amphoricarpus neumayeri Vis.).Glasnik Zemaljskog muzeja Bosne i Hercegovine, 3-4, 159-180.

Gračanin, M., 1950: Mjesečni kišni faktor i njihovo značenje u pedološkim istraživanjima.- Poljoprivredna znanstvena smotra, 12, 51-67.

Hayek, A., 1927-1933: Prodromus Florae peninsulae Balcanicae.- Tom I, pp. 1193; Tom II, pp. 1152; Tom III, pp. 472, Dahlem-Berlin. 
Herak, M., 1983: Geologija.- Školska knjiga, pp.433, Zagreb.

Herak, M., \& V.T. Stringfield, 1972: Karst, important karst regions of the northern hemisphere.- Elsevier Publishing Company, pp. 551, Amsterdam.

Horvat, I., 1933: Istraživanje vegetacije hercegovačkih i crnogorskih planina.- Ljetopis JAZU, 46, 110-113.

Horvat, I., 1941: Istraživanje vegetacije Biokova, Orjena i Bjelašnice.- Ljetopis JAZU, 53, 163-172.

Horvat, I., Glavač, V. \& H. Ellenberg, 1974: Vegetation Südosteuropas.- Gustav Fischer Verlag, pp. 768, Stuttgart.

Horvatić, S., 1963: Biljnogeografski položaj i raščlanjenje našeg Primorja u svjetlu suvremenih fitocenoloških istražianja.- Acta Botanica Croatica, 22, 27-81.

Ilijanić, Lj., 1989: On the sociology of Chrysopogon gryllus in Yugoslavia.- Acta Botanica Croatica, 48, 7582.

Ilijanić, Lj. \& V. Hršak, 1990: Scilla litardierei Breistr. an der nördlichen. Verbereitungsgrenze in Kroatien.Acta Botanica Croatica, 49, 93-100.

Jovanović, B., Lakušić, R., Rizovski, R., Trinajstić, I. \& M. Zupančič, 1986: Prodromus phytocoenosum Jugoslaviae ad mappam vegetation M 1: 200 000.- Naučno vijeće vegetacijske karte Jugoslavije, pp. 51, BribirIlok.

Katzer, F., 1909: Karst und karsthydrographie.- Zur Kunde der Balkanhalbinsel, Reisen und Boebachtungen, Hft. 8. pp. 94, Sarajevo.

Katzer, F., 1926: Geologija Bosne i Hercegovine.- Knjiga 1. Direkcija državnih rudarskih preduzeća u Sarajevu, pp. 527, Sarajevo.

Klimchouk, A., Bayari, S., Nazik, L. \& K. Tork, 2006: Glacial destruction of cave systems in high mountains, with a special reference to the Aladaglar massif, Central Taurus, Turkey.- Acta carsologica, 35,111-121.

Kogovšek, J., Kranjc, A., Slabe, T., \& S. Šebela, 1999: South China Karst 1999, Preliminary research in Yunnan.- Acta carsologica, 28, 225-240.

Kranjc, A., 1994: About the name and the history of region Kras.- Acta carsologica, 23, 81-90.

Kranjc, A., 2002: Intrudaction: Monitoring of carst caves.- Acta carsologica, 31, 9-10.

Kušan, F., 1969: Biljni pokrov Biokova (Flora i vegetacija).- Prirodoslovna istraživanja JAZU, 37, Acta Biologica, 5, 1-224.

Lakušić, R., 1969: Fitogeografsko raščlanjenje visokih Dinarida.- Acta Botanica Croatica, 28, 221-226.

Lakušić, R., 1970: Die Vegetation der Südöstlichen Dinariden.- Vegetatio, 21, 321-373.
Lakušić, R., 1973: Prirodni sistem populacija i vrsta roda Edraianthus DC.- Godišnjak Biološkog instituta, 26, 1-130.

Lakušić, R., 1981: Klimatogeni ekosistemi Bosne i Hercegovine (I).- Geografski pregled, 25, 41-65.

Lakušić, R., Pavlović, D., Abadžić, S. \& P. Grgić, 1978: Prodromus biljnih zajednica Bosne i Hercegovine.Godišnjak Biološkog instituta Univerziteta, 30, 5-87.

Lakušić, R., Pavlović, D., Abadžić, S., Kutleša, L., Mišić, Lj., Redžić, S., Maljević, D. \& S. Bratović, 1979: Struktura i dinamika ekosistema planine Vranice u Bosni.- In: Rauš, Đ. (ed.) Zbornik radova II kongresa ekologa Jugoslavije, knjiga $1,1^{\text {th }}-7^{\text {th }}$ October 1979, Zadar-Plitvice, Savez društava ekologa Jugoslavije, 605-714, Zadar-Plitvice.

Lakušić, R., Pavlović, D., \& S. Redžić, 1982: Horološkoekološka i floristička diferencijacija šuma i šikara sa bjelograbićem (Carpinus orientalis Mill.) i crnim grabom (Ostrya carpinifolia Scop.) na prostoru Jugoslavije.- Glas.Republ.zavoda zašt. Prirode Prirodnjačkog muzeja Titograd, 15, 103-116.

Lakušić, R. \& S. Redžić, 1989: Flora i vegetacija vaskularnih biljaka u refugijalno-reliktnim ekosistemima kanjona rijeke Drine i njenih pritoka.- Glasnik Odjeljenja prirodnih nauka CANU, 7, 107-205.

Lakušić, R. \& S. Redžić, 1991: Vegetacija refugijalno-reliktnih ekosistema sliva rijeke Une.- Bilten Društva ekologa $\mathrm{BiH}, \mathrm{B}, 6,25-73$.

Lepirica, A., 2005: Basic morphological and morphostructural characteristics of the Rakitnica canyon (Dinaric Karst, Bosnia and Herzegovina).- Acta carsologica, 34, 449-458.

Lepirica, A., 2007: Fizičko-geografske karakteristike endemnog razvojnog centra Prenj, Čvrsnica i Čabulja.- In: Redžić, S. (ed.) Biodiverzitet endemnih razvojnih centara na području Hercegovine kao dopinos stremljenjima Targets 2010. Monografija EKO $\mathrm{BiH}, \mathrm{pp} .34-66$, Sarajevo.

Lepirica, A., 2008: Geomorphological characteristics of the massif Prenj.- Acta carsologica, 37, 307-329.

Lučić, I., 2003: Vjetrenica - pogled u dušu zemlje.- ArTresor naklada, pp.322, Zagreb-Ravno.

Magurran, A.E., 1988: Ecological diversity and its measurement.- Princeton University Press, pp. 192, Princeton, New Jersey.

Miladinović, K., 1964: Geološko-tektonski odnosi područja Blidinjeg jezera u Hercegovini.- Geološki glasnik, 9, 129-136.

Milanović, P., 1979: Hidrogeologija karsta $i$ metode istraživanja.- Institut za korištenje i zaštitu voda na kršu, pp. 302, Trebinje. 
Muratspahić, D., Redžić, S., \& R. Lakušić, 1991-1994: Asocijacija Rusco-Carpinetum orientalis Bleč. et Lkšić 1966 u dolini rijeke Neretve.- Glasnik Republ. zavoda zašt. prirode - Prirodnjačkog muzeja, 24, $7-12$.

Murbeck, S., 1891: Beiträge zur Kenntnis der Flora von Südbosnien und der Hercegovina.- pp. 192, Lund.

Oberdorfer, E., 1983: Pflanzensoziologische excursions flora.- Verlag Eugen Ulmer, pp.1051, Stuttgart.

Prohic, E., Hausberger, G. \& J.C. Davis, 1997: Geochemical patterns in soils of the karst region, Croatia.Journal of Geochemical Exploration, 60, 139-155.

Redžić, S., 1997: The Protection of the Diversity of Vascular Plants in the Karst Poljes of the Dinaric Mountains.- In: Sasowsky, I.D., Fong, D.W. \& E.L. White (eds) Conservation and Protection of the Biota of Karst Presentations, Extended abstracts and field trip guide for the conference, $13^{\text {th }}-16^{\text {th }}$ February 1997, Nashville, Tennessee. State College, PA, 82-83,. Nashville.

Redžić, S., 1999: The syntaxonomical differentiation of the Festuco-Brometea Br.-Bl. \& R. Tx. 1943 ex Klika \& Hadač 1944 in the Balkans.- Annali di Botanica, 57, 167-180.

Redžić, S., 2003: The syntaxonomy and syngenesis of the Elyno-Seslerietea Br.-Bl. 1948 in the Balkan peninsula.- Annali di Botanica (nuova serie), 3, 53-74.

Redžić, S., 2004: Biogeographic diferentiation of biodiversity of the Balkan peninsula with reflection at the Bosnia and Herzegovina.- In: Spahić, M. (ed.) Abstract Book of plenary and session lecuters of First congress of geographes of Bosnia and Herzegovina with international participation, $22^{\text {th }}-24^{\text {th }}$ September 2004. Geografsko društvo Bosne i Hercegovine, 23-25, Sarajevo.

Redžić, S., 2007a: Karst fields (poljes) of Dinaric Alps at biodiversity centres with global values.- In: $50^{\text {th }}$ International Association for Vegetation Science Symposium, Abstracts Book, 23 ${ }^{\text {th }}-27^{\text {th }}$ July 2007, Swansea, UK. International Assciation for vegetation science, 47, Swansea.

Redžić, S., 2007b: Role of glaciation centres in the biogeography richness of Balkan peninsula (SE Europa).- In: Third International Biogeography Society Conference, Symposium 2. Quaternary impacts on Holarctic Biogeography, Book of Abstracts, $9^{\text {th }}-13^{\text {th }}$ January 2007, Tenerife, Canary Islands. The international biogeographical society, 45 , Tenerife.

Redžić, S., 2007c: Syntaxonomic diversity as an indicator of ecological diversity - case study Vranica Mts. at the Central Bosnia.- Biologia, Section Botany, 62, $173-184$.
Redžić, S., 2007d: The syntaxonomy of the vegetation of the continental Dinaric Alps (W. Balkan).- Collecion of Papers Devoted to Academician Kiril Micevski, Macedonian Academy of Sciences and Arts, 249-280, Skopje.

Redžić, S., 2008a: Ecohydrological approach to sustainable management of floodable karst fields in Dinaric Alps (Western Balkan).- In: Zalewski, M. (ed.) Abstract of International Conference: "Ecohydrological Processes and Sustainable Floodplain Management", IAP.6, $19^{\text {th }}-23^{\text {th }}$ May 2008, Łodz, Poland. International institute of the Polish academy of sciences European regional centre for ecohydrology under auspice of UNESCO, p. 44, Łodz.

Redžić, S., 2008b: Jasnin encijan Gentiana jasnae (Lakušić) Redžić ukras bosanskih planina.- Fondeko svijet, 26, 22-23.

Redžić, S., 2008c: Sytaxonomic diversity in the evaluation of biodiversity hotspots in Mediterranean region.- In: Chitry, M. (ed.) Abstracts of $17^{\text {th }}$ International Workshop European Vegetation Survey, $1^{\text {th }}-5^{\text {th }}$ May 2008, Brno. Masaryk University, 96, Brno.

Redžić, S., 2008d: The syntaxonomic diversity as a tool in the evaluation of biodiversity hot spots in Mediterranean region.- In: Pešić, V. (ed.) The Book of abstracts and programme of plenary and session lectures of III International Symposium of Ecologist of the Republic Montenegro, $8^{\text {th }}-12^{\text {th }}$ October 2008, Herceg Novi. The Montenegrinian Ecological Society, 33-34, Herceg Novi.

Redžić, S., 2009: Patterns of richness and endemism of vascular plants in biodiversity hotspots in Mediterranean - Central Dinaric Alp.- Biologia, Section Botany (submitted).

Redžić S., Muratspahić, D. \& R. Lakušić, 1992-1994: Some Forests and shrubs phytocoenoses from valley of the Neretva river.- Poljoprivreda \& Šmarstvo, 38, 95-101.

Redžić, S. \& M. Dizdarević, 1998: Biogeografska karta Bosne i Hercegovine. In: Zupčevič, O. (ed.) Atlas svijeta za osnovnu i srednje škole, Sejtarija, pp. 3537, Sarajevo.

Redžić, S. (ed.), 2007: Biodiverzitet endemnih razvojnih centara na području Hercegovine kao doprinos stremljenjima Targets 2010.- Monografija, EKO BiH, pp. 306, Sarajevo.

Redžić, S., Barudanović, S. \& M. Radević (eds.), 2008: Bosna i Hercegovina - zemlja raznolikosti. Pregled $i$ stanje biološke i pejzažne raznolikosti Bosne i Hercegovine.- Federalno ministarstvo okoliša i turizma $\mathrm{BiH}, \mathrm{pp} .164$, Sarajevo. 
Redžić, S. \& S. Barudanović, 2010: The petterns of diversity of forest vegetation of the Crvanj Mountain in the Herzegovina (West Balkan Peninsula). Šumarski list, 134 (5-6), 261-274.

Riter-Studnička, H., 1954: Flora i vegetacija livada kraških polja Bosne i Hercegovine.- Godišnjak Biološkog instituta, 7, 25-109.

Riter-Studnička, H., 1956: Flora i vegetacija na dolomitima Bosne i Hercegovine.- Godišnjak Biološkog instituta, 9, 73-122.

Riter-Studnička, H., 1959: Kraška polja BiH kao reliktna staništa biljaka.- Zaštita prirode, 16, 28-35.

Rodwell, J.S., Schamineé, J.H.J., Mucina, L., Pignatti, S., Dring, J. \& D. Moss, 2002: The diversity of European vegetation: An overview of phytosociological alliances and their relationships to EUNIS habitats.- National Reference Centre for Agriculture, Nature and Fisheries, pp. 168, Wageningen.

Scheiner, S.M., 1992: Measuring pattern diversity.- Ecology, 73, 1860-1867.

Sijarić, R., 2000: Fauna Rhopalocera (Lepidoptera) of Mt. Vran (Herzegovina).- Wissensghaftliche Mitteilungen des Bosnisch-Herzegowinischen Landesmuseums, Naturwissenschaft, Heft C, 7, 325-342.

Sitarz, D. \& P. Simon (eds.), 1993: Agenda 21: The Earth Summit Strategy to Save Our Planet.- Earth Press, Rowley, MA, USA.

Sket, B., 1997: Distribution of Proteus (Amphibia: Urodela; Proteide) and its possible explanation.Journal of Biogeography, 24, 263-280.

Sket, B., Dovč, P., Jalžić, B., Kerovec, M., Kučinić, M. \& P. Trontelj, 2001: A cave leech (Hirudinea, Eepobdellidae) from Croatia with unique morphological features.- Zoologica Scripta, 30, 223-229.

Sliskovic, I., 1995: On the hydrogeological conditions of western Herzegovina (Bosnia and Herzegovina) and possibilities for new groundwater extractions.International Journal of Rock Mechanics and Mining Sciences and Geomechanics Abstracts, 32, 7, 310-311.

Spahić, M., 2001: Prirodna jezera Bosne i Hercegovine: Limnološka monografija.- Harfo-graf, pp.170, Tuzla.

Šilić, Č., 1967: Oreoherzogia pumila (Turra) Vent. subsp. illyrica Šilić, subsp. nova - novi endemični takson zapadnog dijela Balkanskog poluostrva.- Glasnik Zemaljskog muzeja Bosne i Hercegovine, 6, 61-79.
Šilić, Č., 1970: Heliospermo retzdorffiani-Oreoherzogietum illyricae, nova zajednica na hercegovačkim planinama.- Radovi Akademije nauka i umjetnosti $\mathrm{BiH}$, Posebna izdanja 15, Odjeljenje prirodnih i matematičkih nauka, 4, 303-311.

Šilić, Č., 1979: Monografija rodova Satureja L., Calamintha Miller, Micromeria Bentham, Acinos Miller $i$ Clinopodium L. u flori Jugoslavije.- Zemaljski muzej $\mathrm{BiH}$, pp. 440, Sarajevo.

Šilić, Č., 1984: Endemične biljke.- Svjetlost, Zavod za udžbenike i nastavna sredstva, pp. 227, Sarajevo.

Šilić, Č., 2000: Šilić, Č., 2000: List of species (Pteridophyta and Spermatophyta) for the "Red Book" of Bosnia and Herzegovina.- Wissensghaftliche Mitteilungen des Bosnisch-Herzegowinischen Landesmuseums, Naturwissenschaft, Heft C, 7, 287-322.

Šilić, Č., 2002: Endemične i rijetke biljke Parka prirode Blidinje.- Matica hrvatska, Ogranak Čitluk, pp. 279, Čitluk.

Topić, J. \& Lj. Ilijanić, 2005: Campanula kapelae, the new species? within Campanula pyramidalis agg.- Natura Croatica, 14, 3, 249-253.

Trinajstić, I., 2008: Biljne zajednice Republike Hrvatske.Akademija šumarskih znanosti, pp. 179, Zagreb.

Tutin, T.G., Heywood, V.H., Burges, N.A., Valentine, D.H., Walters, S.M. \& D.A. Webb, 1964-1980: Flora Europea- Vol. I-V. Cambridge University Press, Cambridge.

Verovnik, R., Sket, B. \& P. Trontelj, 2004: Phylogeography of subterranean and surface population of water lice Asellus aquaicus (Crustacea: Isopoda).- Molecular Ecology, 13, 1519-1532.

Weber, H.E., Moravec, J. \& J.P. Theurillat, 2000: International Code of Phytosociological Nomenclature. 3rd edition.- Journal of Vegetation Science, 11, 739-768.

White, W.B., 1988: Geomorphology and Hydrology of Karst Terrains.- Oxford University Press, pp. 464, New York. 